\title{
Individual capital and social entrepreneurship: Role of formal institutions
}

\section{Authors}

1. Sreevas Sahasranamam (Corresponding Author)

Lecturer \& Chancellor's Fellow,

Hunter Centre for Entrepreneurship

Strathclyde Business School,

Glasgow, UK

Email: sreevas.sahasranamam@strath.ac.uk

Phone: +44 - 01415484598

2. M.K. Nandakumar

Indian Institute of Management Kozhikode (IIMK)

IIMK Campus P. O.,

Kozhikode, Kerala, India

PIN - 673570

Email: nmkveettil@gmail.com

Phone: +91 (0) 495-280-9256

\section{Acknowledgements:}

We would like to thank the Editors and the two anonymous reviewers for their insightful comments and suggestions during the review process. They have engaged in a constructive dialogue and this has helped us to improve the manuscript substantially.

The first author will like to thank Strategic Management Society (SMS)'s Strategic Research Foundation (SRF) dissertation fellow grant (Grant no: SRF-DP2014-132) for its funding support and mentoring in developing this manuscript.

Forthcoming in Journal of Business Research 


\begin{abstract}
Drawing on capital theory and institutional theory, we hypothesize the contingent role of a country's formal institutions (financial, educational, and political) on the relationship between individual capital (financial, human and social capital) and social entrepreneurship entry. Using the Global Entrepreneurship Monitor data, we find that all three forms of individual capital are important for social entrepreneurship entry. Moreover, we find that this relationship is contingent on the formal institutional context such that (i) philanthropy-oriented financial systems have a positive moderating effect on investment of financial capital; (ii) educational systems have a positive moderating effect on investment of human capital; and (iii) political systems have a positive moderating effect on investment of both human and financial capital. We make substantial contributions to the literature on social entrepreneurship by ascertaining the nature of contingent effects of formal institutions on the relationship between individual capital and the emergence of social enterprises.
\end{abstract}

Keywords: Social entrepreneurship, Institutional theory, Capital theory, Formal institutions, Global Entrepreneurship Monitor.

\title{
1. Introduction
}

Social enterprises have gained prominence in the recent years mainly because of their ability to address pressing global concerns (Agarwal, Chakrabarti, Brem, \& Bocken, 2018; Sakarya, Bodur, Yildirim-Öktem, \& Selekler-Göksen, 2012; Stephan, Patterson, Kelly, \& Mair, 2016; Viswanathan \& Rosa, 2010). There are multiple definitions of social entrepreneurship: addressing social needs that are not met by commercial enterprises (McMullen, 2011); facilitating social change through innovative approaches (Nicholls, 2008); satisfying unmet needs (Thompson, Alvy, \& Lees, 2000); creating social value through market-based initiatives (Bacq \& Janssen, 2011); combining social mission and attributes of commercial businesses 
(Dees, 1998); and pursuing opportunities in an innovative way to catalyze social change and address social needs (Mair \& Martí, 2006). Social enterprises can be compared with commercial enterprises in terms of indicative and functional perspectives (Bacq \& Janssen, 2011; Casson, 1982). Based on the indicative perspective, pro-social motivations are considered to be a distinguishing characteristic of social enterprise founders (Grimes, McMullen, Vogus, \& Miller, 2013; Miller, Grimes, McMullen, \& Vogus, 2012). From a functional perspective, social enterprises differ from commercial enterprises in aspects such as mission, performance measurement, opportunity perception, temporal view and organizational form (Austin, Stevenson, \& Wei-skillern, 2006; Dacin, Dacin, \& Matear, 2010). For instance, social and commercial enterprises differ in the way they reinvest their profits (Bacq \& Janssen, 2011). While social enterprises reinvest their profits towards the achievement of their social mission, commercial enterprises divide the profits generated among their investors or reinvest in the business activities. The inability of social enterprises to redistribute their profits to their investors and employees potentially results in a competitive disadvantage for them (Costanzo, Vurro, Foster, Servato, \& Perrini, 2014). In short, social enterprises have to balance both social and economic objectives, while commercial enterprises largely emphasize financial return (Battilana \& Lee, 2014; Estrin, Mickiewicz, \& Stephan, 2016; Rey-Martí, Ribeiro-Soriano, \& Sánchez-García, 2016). Due to their social objectives, the external factors play a more significant role in shaping the strategies of social enterprises in comparison to commercial enterprises (Gras \& Lumpkin, 2012; Pathak \& Muralidharan, 2016).

The individual capital of the entrepreneurs, such as human, financial and social capital, are very crucial in the creation of new ventures (De Clercq, Lim, \& Oh, 2013; Marvel, Davis, \& Sproul, 2016; Xavier-Oliveira, Laplume, \& Pathak, 2015). However, limited research has been undertaken to examine the role played by individual capital on social entrepreneurship entry despite the above-mentioned differences in the characteristics of social enterprises (Estrin 
et al., 2016; Hechavarría et al., 2017; Terjesen, Hessels, \& Li, 2016). Following the recommendation by Terjesen et al. (2016) and drawing insights from Estrin et al. (2016), we use the lenses of capital theory (Becker, 1994; Bourdieu, 1986) and institutional theory (North, 1990; Whitley, 1999) to examine how formal institutions affect the impact of individual capital (financial, human and social) on social enterprise entry.

Based on capital theories (Becker, 1994; Bourdieu, 1986; Dollinger, 1995), we know that new business creation requires substantial levels of individual capital (De Clercq et al., 2013; Mickiewicz, Nyakudya, Theodorakopoulos, \& Hart, 2017). According to capital theory (Bourdieu, 1986; Dollinger, 1995), financial, human and social capital are the key forms of individual capital. The financial capital of an entrepreneur refers to their cash reserves and other liquid assets, such as stocks and bonds (Lumpkin, Bacq, \& Pidduck, 2018). Human capital theory suggests that people strive to develop their human capital through education and by attending other training events with the expectation that they will obtain sufficient returns for their investment during their lifetime (Becker, 1994). In an entrepreneurial context, entrepreneurs who make substantial investments in their human capital expect to obtain rewards from their new ventures (Marvel et al., 2016; Rauch \& Rijsdijk, 2013). Social capital refers to the networks and relationships that entrepreneurs can rely on for support (Bhagavatula, Elfring, van Tilburg, \& van de Bunt, 2010; Nahapiet \& Ghoshal, 1998). Therefore, our study focuses on the role of these three forms of individual capital on social entrepreneurship entry.

Regardless of whether it is commercial or social, entrepreneurship requires action (McMullen \& Shepherd, 2006), which in turn requires ability, motivation, and opportunity (McMullen \& Dimov, 2013). Like markets, these elements of entrepreneurial agency are embedded in social structures (Autio, Pathak, \& Wennberg, 2013; Granovetter, 1985; Jack \& Anderson, 2002; Miller et al., 2012), such that they are likely to be influenced by institutions (Baumol, 1990; North, 1990). The increased ability to act entrepreneurially because of greater 
endowments of individual capital is subject to institutional influence via the elements of both opportunity and motivation (Aragon-Mendoza, del Val, \& Roig-Dobón, 2016; Kshetri, 2009; Welter, 2011). Formal institutions, such as the financial system, educational system, and political system, systematically facilitate or suppress various entrepreneurial actions by providing or denying various opportunities for profit to be realized via certain avenues (Bowen \& De Clercq, 2008; De Clercq et al., 2013). For example, one cannot start a social enterprise like Grameen Bank if laws about public finance disallow it, but if they have substantial resources, individuals may turn entrepreneurial attention elsewhere as opposed to abandoning entrepreneurship altogether. This introduces social costs or benefits into an individual's decision making, which complement or contradict the economic calculus that they use to choose which type of enterprise to start. Thus, formal institutions are likely to moderate the relationship between individual capital and social entrepreneurial entry.

Prior studies on this topic within social entrepreneurship have either focused on a limited set of countries (Bacq, Hartog, \& Hoogendoorn, 2013, 2016), or studied the effect of individual factors and institutions on social enterprises separately (Estrin et al. 2013; Hechavarría 2015; Hechavarria et al. 2012; Stephan et al. 2015), or have considered the role of only one of the institutional factors (Estrin et al., 2016). The phenomenon of social entrepreneurship can be better understood by examining the impact of multiple institutional factors (Muñoz \& Kibler, 2016). Our study extends this research area by considering the contingent role of multiple formal institutions (financial, educational and political system) across countries on investment of individual capital in social entrepreneurship entry. Based on capital theory and institutional theory, we explore how commercial financial systems, philanthropy-oriented financial systems, educational systems and political systems moderate the impact of individual capital on social entrepreneurship entry. To test our hypotheses, we collected data from the Global Entrepreneurship Monitor (GEM) (Lepoutre, Justo, Terjesen, \& 
Bosma, 2013; Reynolds et al., 2005; Terjesen, Lepoutre, Justo, \& Bosma, 2012) and merged that data with other country-level indicators.

We make multiple contributions through this study. Firstly, utilizing capital theory, we contribute to the research on the role of individual characteristics in social entrepreneurship (Hechavarría et al., 2017; Stephan et al., 2016) by examining the role of financial, human and social capital in social entrepreneurship entry. Secondly, we contextualize the effect of individual capital on social entrepreneurship by studying the contingent effect of formal institutions on investment of individual capital in social entrepreneurship entry. As a result of ascertaining the direct effects of individual capital on social entrepreneurship entry and the contingent effects of formal institutions on this relationship, we contribute to the growing research in this stream of literature on entrepreneurship (De Clercq et al., 2013; Estrin et al., 2016; Marvel et al., 2016; Terjesen et al., 2016). Plenty of research has been done examining these relationships in the context of commercial entrepreneurship (Autio \& Acs, 2010; Bhagavatula et al., 2010; Boudreaux \& Nikolaev, 2018; Davidsson \& Honig, 2003; De Clercq et al., 2013). We compare our findings in the context of social entrepreneurship with those in the context of commercial entrepreneurship and make a contribution to the literature (Austin et al., 2006; Estrin et al., 2013, 2016; Hechavarría, 2016), by highlighting the similarities and differences in the role played by formal institutions in these two.

The remainder of this paper is arranged as follows. The next section highlights the theory and develops the hypotheses - the relationships between individual capital and social entrepreneurship choice and the moderating effects on this relationship of formal institutions at the country level. Then, we describe our data, methods, and analysis. Finally, we discuss our findings, and conclude with limitations and directions for future research.

\section{Theory and hypotheses}


Much of the early literature on social entrepreneurship was aimed at characterizing it as a distinct category separate from commercial entrepreneurship (Austin et al., 2006; Dacin, Dacin, \& Matear, 2010). At an organizational mission level, commercial enterprises are aimed at creating private gains, while social enterprises create social value for public gain (Dacin et al., 2010). Consequently, their respective measures of performance are quite different. Commercial enterprises use conventional performance measures such as market share, return on assets or stock market returns. Social change is however a complex measure, as it is non-quantifiable, multi-causal and temporal (Austin et al., 2006). Therefore, social enterprises find it hard to measure their performance, though impact measurement techniques are beginning to gain popularity and legitimacy (Block, Colombo, Cumming, \& Vismara, 2018; Millar \& Hall, 2013). Owing to the limited financial profits that social enterprises create, they are often dependent on bricolage approaches, volunteers and social alliances for resource mobilization (Desa, 2012; Sahasranamam \& Ball, 2016; Sakarya et al., 2012; Sharir \& Lerner, 2006).

New business creation requires substantial resources (Bourdieu, 1986; Davidsson \& Honig, 2003; Venkataraman, 1997), which are sourced from internal and external environments (Cai, Hughes, \& Yin, 2014). Because the external environment of a country poses restrictions on the individual's ability to start a new business (Baker et al. 2005), research in entrepreneurship has suggested that factors at multiple levels influence the new business creation process (Davidsson \& Wiklund, 2001). These include individual-level capital (Bhagavatula et al., 2010; Davidsson \& Honig, 2003) and regional- or national-level contextual factors (Bowen \& De Clercq, 2008; Welter, 2011). This interaction between the individualand the country-level context makes it nearly impossible to examine entrepreneurship through individual capital alone without considering the broader context (Bull, 2018; De Clercq et al., 2013; Shane \& Venkataraman, 2000). Hence, we consider a multilevel model of individual- 
and country-level effect on social entrepreneurship entry. Figure 1 illustrates this conceptual model.

Insert Figure 1 here

\subsection{Individual capital and social entrepreneurship entry}

Prior research has typologized capital into different forms. This includes physical capital (Hofer \& Schendel, 1978), financial capital (Churchill \& Bygrave, 1990; Minniti \& Bygrave, 1999), human capital (Becker, 1994), social capital (Bourdieu, 1986; Granovetter, 1985; Nahapiet \& Ghoshal, 1998), cultural capital (Bourdieu, 1986; Dana \& Light, 2011) and organizational capital (Dollinger, 1995; Hofer \& Schendel, 1978; Tomer, 1987). For entrepreneurs, especially those in the nascent stages of an endeavor, financial, human and social capital are considered to be the most important forms of individual capital (Boudreaux \& Nikolaev, 2018; Davidsson \& Honig, 2003; De Clercq et al., 2013). Therefore, we focus on the role of these three forms of individual capital on social entrepreneurship entry in this study.

\subsubsection{Financial capital and social entrepreneurship entry}

Generally, entrepreneurs initiate the start-up process without gaining control of many resources that are necessary for the new venture creation. This holds well in the case of social enterprises as well. Financial capital forms a critical component of the resource bundle, and entrepreneurs with limited access to this resource find it quite demanding to attract external support (Wright, Lockett, Clarysse, \& Binks, 2006). Financial capital is usually a function of household income level (Kim, Aldrich, \& Keister, 2006; Xavier-Oliveira et al., 2015). Empirical evidence suggests that both family wealth and personal wealth are key factors that influence people in becoming entrepreneurs (Blanchflower \& Oswald, 1998; Sahasranamam \& Sud, 2016; XavierOliveira et al., 2015). Financial capital has a significant positive relationship with the likelihood of becoming an entrepreneur (Cetindamar, Gupta, Karadeniz, \& Egrican, 2012). Financial 
capital also helps the new venture to survive after its inception and to facilitate its growth (Cooper, Gimeno-Gascon, \& Woo, 1994). The entrepreneurs primarily drive the venture creation process and hence it is desirable that a substantial amount of financial capital is available with them.

Even though there are differences between commercial and social enterprises (mainly in terms of value creation), financial capital is a key resource for both commercial and social enterprises. Many social enterprises become predominantly reliant on individual financial capital due to a lack of legitimacy of their organizational form (Dart, 2004; Mair \& Marti, 2009). This limits their opportunities to source financing from external sources during the entrepreneurial entry phase (Agarwal et al., 2018; Dart, 2004; Desa, 2012). Therefore, we posit that those individuals who have higher stock of individual financial capital are more likely to make social entrepreneurship entry.

H1a. There is a positive relationship between individual financial capital and the likelihood of social entrepreneurship entry.

\subsubsection{Human capital and social entrepreneurship entry}

Human capital refers to the educational and skill levels of the individual (Becker, 1994). There are two types of human capital - general and specific human capital (Becker, 1994). General human capital refers to educational qualifications, while entrepreneur specific human capital refers to having the knowledge, skills and experience to run a business (Marvel et al., 2016; Unger, Rauch, Frese, \& Rosenbusch, 2011). An individual who has higher human capital is in a better position to identify and exploit new business opportunities (Autio \& Acs, 2010; Mickiewicz et al., 2017; Rauch \& Rijsdijk, 2013). Literature also suggests that entrepreneurs can create successful new ventures even without substantial financial capital provided they have high levels of human capital (Kim et al., 2006). Empirical evidence suggests that though both forms of human capital are likely to influence entrepreneurship entry, the contingent effect 
of institutional context in the country will only be on the investment of specific human capital (Baumol, 1990; Estrin et al., 2016). Therefore, we focus on entrepreneurship-specific human capital in this study.

Entrepreneurship-specific human capital has similar beneficial roles in both commercial and social entrepreneurship entry, since many aspects of the respective venture creations are shared (Estrin et al., 2016). For instance, having knowledge, skills and experience required for new venture creation will equip social entrepreneurs to better utilize opportunities and resources (Dacin et al., 2010; Rey-Martí et al., 2016). They will also be better equipped to overcome the obstacles associated with starting a new business (Meyskens, Robb-Post, Stamp, Carsrud, \& Reynolds, 2010). Moreover, higher stock levels of human capital are also critical for social entrepreneurship during the entry phase in the absence of sufficient external legitimacy (Agarwal et al., 2018; Dart, 2004). Hence, we expect that individuals with higher human capital are more likely to become social entrepreneurs.

H1b. There is a positive relationship between individual human capital and the likelihood of social entrepreneurship entry.

\subsubsection{Social capital and social entrepreneurship entry}

Social capital is a resource that individuals derive from their social structures (Baker, 1990; Bourdieu, 1986). It refers to friends, colleagues and other contacts through whom they are likely to identify opportunities and support (Burt, 1997; Burt, 1992). Social capital explains social interactions at multiple levels in the entrepreneurial process (Gedajlovic, Honig, Moore, Payne, \& Wright, 2013). It is highly beneficial to entrepreneurs both individually and collectively (McKeever, Anderson, \& Jack, 2014). When individuals have exposure to other entrepreneurs, they can rely on them for advice and support regarding the new venture (Klyver, Hindle, \& Meyer, 2008). Social capital provided by family, community, or organizational relationships helps supplement education, experience and financial capital (Bourdieu, 1986; 
Coleman, 1988). These networks are likely to offer resource support (Sahasranamam \& Sud, 2016; Stam, Arzlanian, \& Elfring, 2014) and increase awareness about entrepreneurship (Minniti \& Nardone, 2007). It should also be noted that greater social capital provides better emotional support and decreases uncertainty (Manolova, Carter, Manev, \& Gyoshev, 2007), which are very helpful during the difficult process of new venture creation.

As highlighted earlier, social entrepreneurs are seeking to attract resources primarily for the social good, as opposed to financial returns. Owing to the limited financial returns they make, social entrepreneurs may choose or be forced to rely more on their network of contacts and social capital for accessing the necessary resources (Austin et al., 2006; Desa \& Basu, 2013). Indeed, it also quite possible that the size of an individual's network and social capital are indicative of that person's involvement in social engagement (Kachlami, Yazdanfar, \& Öhman, 2018; Putnam, 2000), which may itself lead that person towards social entrepreneurship. Hence, we expect that individuals with higher social capital are more likely to become social entrepreneurs.

H1c. There is a positive relationship between individual social capital and the likelihood of social entrepreneurship entry.

\subsection{National business systems - Formal institutions}

We conceptualize national institutional context on the basis of the New Institutional Economics (NIE) perspective of North (1990). According to North (1990), institutions are the rules of the game that structure human interactions in a society. NIE specifies the institutional framework as consisting of formal structures of rules and regulations that control socioeconomic behavior, and the system of informal relations involving customs, norms and social routines. Scott (2001), building on prior research efforts (DiMaggio \& Powell, 1991; North, 1990), more finely categorized formal and informal institutions into normative, regulatory, and cognitive 
groupings. Regulatory institutions represent the standards provided by laws and other sanctions. Normative institutions, which tend to be less formal and define the roles or actions expected of individuals, often manifest through accepted authority systems such as accounting or medical professional societies. Sometimes they are codified, other times they are the implicit practices of a profession or work function. Finally, cultural-cognitive institutions represent the most informal, taken-for-granted rules and beliefs established through social interactions and behavior among individuals. A principal means by which this institution propagates and influences a society is through the community's culture (Scott, 2001).

National cultures and formal institutions play major roles in promoting entrepreneurial initiatives across nations (Dheer, 2017). Baumol's (1990) is among the earliest works to argue that the way a society is organized influences entrepreneurship. Entrepreneurship scholars have observed that the National Business System (NBS) (Whitley, 1999) perspective (based on the NIE lineage) both complements Baumol's (1990) work and offers specific dimensions of national institutional context that could explain why entrepreneurial endeavors differ across countries (Bowen \& De Clercq, 2008; Kshetri, 2009). Therefore, we have chosen the NBS framework as the foundation for developing our theoretical arguments on the institutional context.

According to Whitley (1992, p. 13), NBS is defined as the "distinctive configurations of hierarchy market relations which become institutionalized as relatively successful ways of organizing economic activities in different institutional environments." In seeking to explain cross-country differences in the organization and behavior of firms, Whitley (1999) argues that variations in societal institutions play an important role in guiding economic behavior and identifies the key environmental dimensions influencing the behavior of entrepreneurs - in particular, their choice to allocate capital towards starting an enterprise. Whitley's (1999) NBS perspective classifies the institutional context into formal and informal institutions. The formal 
institutions contain sub-categories such as financial system, educational system, and political system. The financial system refers to the processes by which capital is made available and priced. The educational system involves the ways in which skills are developed and controlled. The political system refers to the extent to which the state regulates markets and encourages the establishment of economic associations. How these conditions influence the deployment of individual capital in pursuit of social entrepreneurship remains relatively unexplored, despite claims that formal institutions could explain the cross-country variation in social enterprise emergence (Estrin et al., 2013, 2016; Terjesen et al., 2016).

\subsubsection{Individual financial capital, financial system and social entrepreneurship entry}

The first dimension of the institutional context that influences entrepreneurship is the financial system. The liquidity of financial systems influences entrepreneurial thinking and tends to vary along a continuum between equity-focused financial systems and bank-based financial systems, which is the process by which capital is made available and priced (Whitley, 1999, p. 49). Commercial entrepreneurship focusses on these multiple commercial financial sources like commercial banks, mutual funds, and financial markets (Gimmon \& Levie, 2010; Vanacker, Collewaert, \& Paeleman, 2013). In the case of social entrepreneurship, there exist additional philanthropic forms of capital such as grants and donations (Block et al., 2018; Teasdale, 2010).

Entrepreneurs often require substantial financing from outside owing to limited personal wealth (Blanchflower \& Oswald, 1998; Caputo \& Dolinsky, 1998; Grichnik, Brinckmann, Singh, \& Manigart, 2014). The resourcefulness of the individual in terms of his financial capital acts as a signal of credibility to providers of external finance (Arthurs, Busenitz, Hoskisson, \& Johnson, 2009; Gimmon \& Levie, 2010). However, different providers of external finance are likely to decide their financial support based on the nature and magnitude of return they expect to make from the investment. In this regard, the dual mission of a social enterprise (Moss, 
Short, Payne, \& Lumpkin, 2011) can both help and hinder access to external financial investment. The dual mission is often a source of confusion for commercial financial investors (Bridgstock, Lettice, Özbilgin, \& Tatli, 2010). The pursuit of a social return may limit the magnitude of financial return from the enterprise, making the investment less attractive to many for-profit commercial investors (Moore, Westley, \& Nicholls, 2012). Furthermore, for these commercial investors, social enterprise products and services might not fit neatly into established funder categories (Bridgstock et al., 2010). Therefore, the pursuit of both social return and financial return create conflicting goals (Smith et al., 2013) making them less attractive to traditional commercial investors. In other words, from a cognitive view (Islam, Fremeth, \& Marcus, 2018; Suchman, 1995), the limited public knowledge and lack of established reference models lowers the legitimacy of social entrepreneurship in the eyes of commercial financiers. Furthermore, in countries where the commercial financial system is dominant, there may be strong norms that favor financial return on investment. Consequently, there is a strong likelihood of exclusion of alternate norms (social return on investment) as suggested by the social capital literature that dwells on its negative consequences (Waldinger, 1995; Woolcock, 1998). Such exclusion of alternate norms is likely to discourage investment of individual financial capital in social entrepreneurship entry in a commercial financial system.

H2a. The relationship between individual financial capital and the likelihood of social entrepreneurship entry is negatively moderated by a country's commercial financial system.

When viewed from another perspective, socially minded or philanthropic investors, like foundations and grant givers, would not be interested in capitalizing on a social enterprise as a traditional for-profit business (Block et al., 2018). Rather, from a cognitive view, such investors are more likely to understand the activities of a social enterprise and bestow legitimacy on them 
given their experience of working in the social sector (e.g. NGOs, foundations) (McKnight \& Zietsma, 2018; Suchman, 1995). Teasdale (2010) suggests that social enterprises draw on different aspects of their dual identity to attract grant funding, private donations, and other forms of philanthropy. The dual mission of the social enterprise also makes them eligible for public funding and contracts to deliver public services (Bridgstock et al., 2010; Mullins, Czischke, \& van Bortel, 2012; Munoz \& Tindsley, 2008). Sunley and Pinch (2012) found that the majority of social enterprises rely on public-sector grants and are cautious about adding debt to their financing structure. In addition, social investment funds have started in some countries that offer finances to social enterprises at terms that are more favorable (Block et al., 2018). This evolving category of funds seek opportunities to lend to organizations that create social value at the same time as generating some financial return (Nicholls, 2010). This includes investments that offer loans at preferential terms for social enterprises and philanthropic venture capital, such as the Acumen Fund (Scarlata \& Alemany, 2010). Considering that in philanthropic-oriented financial systems, there is a presence of strong norms in favor of social return from social enterprises, we posit that such will support investment of individual financial capital in social entrepreneurship entry.

H2b. The relationship between individual financial capital and the likelihood of social entrepreneurship entry is positively moderated by a country's philanthropy-oriented financial system.

\subsubsection{Individual human capital, educational system and social entrepreneurship entry}

The second dimension of the institutional context in which entrepreneurs are embedded pertains to institutions that develop individuals' competences and skills, of which the educational system is a key component (Whitley, 1999). New ventures depend on a supply of skilled labor and this particular institution deals with the human resources that are available to privately owned economic actors (Whitley, 1999). Countries with well-developed educational 
systems generally prepare entrepreneurs for the hardships of starting a new business through better training. Hence, a country's educational system affects individuals' decisions to start new businesses (Levie \& Autio, 2008; Van de Ven, 1993). Thus, it is likely that individuals from a country with a higher quality education system will perceive the environment as more entrepreneurially munificent because these individuals have better access to high-quality human resources (Begley, Tan, \& Schoch, 2005).

Social enterprises do not operate on market rates and hence often do not have sufficient financial resources to pay market rates to their employees (Austin et al., 2006). Therefore, they rely on non-financial resources to motivate their employees (Dees 1998). Prior research finds that the social component of the dual mission enables social entrepreneurs to recruit (Battilana \& Dorado, 2010) and mobilize effort from employees, volunteers, and supporters (Haugh, 2007; Thompson et al., 2000). It is observed that social mission acts as a motivating force that provides employees with job satisfaction via intrinsic rewards as well as a sense of fulfilment derived from contributing to their community (Bacchiega \& Borzaga, 2001). Such nonpecuniary rewards are used to recruit and motivate paid staff and unpaid volunteers for social enterprises (Battilana \& Dorado, 2010). The quality of and access to such volunteers is influenced greatly by the educational levels of a country (Astin, Keup, \& Lindholm, 2002; Forbes \& Zampelli, 2014; Peterman \& Kennedy, 2003). Based on a cross-country study, Schofer and Fourcade-Gourinchas (2001) found that voluntary association membership is higher in more educated societies. Recent research from Sweden also observed that higher levels of education within a region led to greater civic engagement (Kachlami et al., 2018). This suggests that the educational system aids in setting up a normative environment that provides legitimacy to social enterprises and aids in its external resource acquisition requirements. Hence, a greater spirit of volunteerism and pro-social motivations enabled by the educational system of the country are likely to have a complementary effect enhancing 
investment of entrepreneurship-specific human capital in social entrepreneurship entry. Therefore, we posit a positive moderating effect of a country's educational system on the relationship between human capital and social entrepreneurship entry.

H3. The relationship between human capital and the likelihood of social entrepreneurship entry is positively moderated by a country's educational system.

\subsubsection{Individual capital, political system and social entrepreneurship entry}

The third dimension of a country's institutional context expected to influence the allocation of entrepreneurial activity is the role of the state or government (Whitley, 1999). Prior research in the commercial entrepreneurship literature has argued that regulatory structure and laws present an extra hurdle for people considering an entrepreneurial career (Djankov, Porta, Lopez-De-Silanes, \& Shleifer, 2002). Rule of law in a country indicates the degree to which rules and regulations are implemented, and it is widely used as a measure of the quality of governance (Estrin \& Mickiewicz, 2011; Estrin et al., 2016; Levie \& Autio, 2011). In countries where rule of law is weak, corrupt and unfair practices increase transaction costs (Estrin \& Mickiewicz, 2011; Sahasranamam \& Raman, 2018) and hinder entrepreneurial activity (Goltz, Buche, \& Pathak, 2015). However, in countries where rule of law is strongly established, the risk levels for investments decline significantly, resulting in the creation of many new ventures in those countries (Levie \& Autio, 2011).

Rule of law in a country characterizes its regulatory context determining the extent to which potential returns from individual capital investments can be captured by the individual or their firm. When the rule of law in a country is weak, the threat of expropriation could lead individuals to direct their individual resource investments towards alternate occupations (Autio \& Acs, 2010; Sahasranamam \& Raman, 2018) rather than social (or commercial) entrepreneurship. Therefore, better rule of law coupled with support from the government in the form of tangible and intangible resources (Evans, 1996; Korosec \& Berman, 2006; Zahra 
\& Wright, 2011) will act as a means of offering pragmatic legitimacy to social enterprises (Dart, 2004). Support in the form of tangible resources could be in the form of grants, subsidies, and other means of direct funding from the government (Block et al., 2018; Henderson, Reilly, Moyes, \& Whittam, 2018). It may also entail either the creation of separate legal structures for social enterprises, which enhances their legitimacy, or promulgation of regulations that increase the potential funding for social enterprises (Haigh, Kennedy, \& Walker, 2015; Sahasranamam \& Ball, 2018; Subramaniam, Kansal, \& Babu, 2017). Less tangible resources provided to social entrepreneurs could be in the form of assistance for completion of grant applications, or hosting events that offer networking opportunities (Korosec \& Berman, 2006; Meyskens, Carsrud, \& Cardozo, 2010; Meyskens, Robb-Post, et al., 2010). Because government and social enterprises share the objective of addressing the social problems of their context, they are to some degree natural partners trying to achieve social goals (Stephan et al., 2015; Sud, van Sandt, \& Baugous, 2009). The degree of resourcefulness exhibited by social entrepreneurs through their stock of individual capital (financial, human and social capital) sends out a positive signal to attract such support from the political system. Hence, higher stock of individual capital investment in social entrepreneurship entry is likely to be strengthened by the political system of the country. Thus,

H4a. The relationship between financial capital and the likelihood of social entrepreneurship entry is positively moderated by a country's political system.

H4b. The relationship between human capital and the likelihood of social entrepreneurship entry is positively moderated by a country's political system.

H4c. The relationship between social capital and the likelihood of social entrepreneurship entry is positively moderated by a country's political system. 


\section{Data and methods}

\subsection{Data source}

We rely on the Adult Population Survey (APS) collected by the Global Entrepreneurship Monitor (GEM) as the primary source of our data. GEM annually collects the data on a national basis. They have been collecting the data through a detailed survey at an individual level since 1999. As part of the data collection effort, GEM collaborates with academic institutions in various countries to collect the data. More than 70 countries have participated in the survey, and this represents about three-quarters of the global population and 90\% of the world's GDP (Amorós \& Bosma, 2013). The data and methodology are detailed on the GEM website (www.gemconsortium.org).

In 2009, GEM had a special focus on social entrepreneurship and contained questions uniquely constructed to address our theoretical concerns. Studies have judged the GEM survey to be notably rich, reliable, and valid (Reynolds et al., 2005), whereby in each country, private market survey firms annually conduct the Adult Population Survey with a representative weighted sample of at least 2000 adults (aged 18-64 years) through telephone (or occasionally face-to-face) interviews (Lepoutre et al., 2013; Levie \& Autio, 2008). Recent entrepreneurship and international business research has relied heavily on this data (Aragon-Mendoza et al., 2016; Beynon, Jones, \& Pickernell, 2018; Mickiewicz et al., 2017).

The survey instrument for the 2009 social entrepreneurship survey was developed via earlier pilot studies, ${ }^{1}$ and its questions were anchored in the social entrepreneurship literature (Lepoutre et al., 2013). With very few exceptions, the data for each country consists of representative samples of at least 2,000 individuals drawn from the working age population, which avoids the potential selectivity bias of studies restricted only to existing entrepreneurs.

\footnotetext{
${ }^{1}$ Implemented by the UK team (Harding 2006; Harding \& Cowling 2004; Levie et al., 2006).
} 
We merged this data set on entrepreneurship (covering individual observations from across 53 countries $^{2}$ in 2009) with national institutional context data from World Bank, United National Human Development Index, World Giving Report and Heritage Foundation to construct our own sample.

\subsection{Variables}

\subsubsection{Dependent variable.}

The dependent variable considered for this study is social entrepreneurship entry. We measure this as a binary variable, which equals 1 if the respondent answered in the affirmative that they 'alone or with others is/are currently trying to start any kind of activity, organization, or initiative that has social, environmental, or community objectives or is currently the ownermanager of an organization with such objectives' ${ }^{3}$ (Lepoutre et al., 2013; Stephan et al., 2015; Terjesen et al., 2012). This classification of a social enterprise is consistent with prior literature (Mair \& Martí, 2006; Zahra et al. 2009).

\subsubsection{Independent variables.}

We operationalized entrepreneurship-specific human capital as a dummy variable, equal to 1 when respondents indicated that they had the knowledge, skills and experience required to start a new business (De Clercq \& Arenius, 2006; De Clercq et al., 2013; Minniti \& Nardone, 2007). It captures respondents' perceptions of their capabilities to launch a business. Financial capital is a dummy variable, equal to 1 , when a respondent indicated that they belonged to the middle

\footnotetext{
2 Algeria, Argentina, Belgium, Bosnia \& Herzegovina, Brazil, Chile, China, Colombia, Croatia, Denmark, Dominican Republic, Ecuador, Finland, France, Germany, Greece, Guatemala, Hong Kong, Hungary, Iceland, Iran, Israel, Italy, Jamaica, Japan, Jordon, Latvia, Lebanon, Malaysia, Morocco, Netherlands, Norway, Panama, Peru, Romania, Russia, Saudi Arabia, Serbia, Slovenia, South Africa, South Korea, Spain, Switzerland, Syria, Tonga, Tunisia, Uganda, United Arab Emirates, United Kingdom, United States, Uruguay, Venezuela, and Yemen.

${ }^{3}$ The exact question is: Are you, alone or with others, currently trying to start or currently owning and managing any kind of activity, organization or initiative that has a particularly social, environmental or community objective? This might include providing services or training to socially deprived or disabled persons, using profits for socially oriented purposes, organizing self-help groups for community action, etc.(Global Entrepreneurship Monitor, 2009).
} 
or higher income group of the country. This approach is consistent with prior studies (Arenius \& Minniti, 2005; Autio \& Acs, 2010). We measure social capital as a dummy variable, equal to 1 when respondents indicated that they personally knew someone who had started a business in the past two years (De Clercq et al., 2013; Klyver et al., 2008). We obtained the data for these from the GEM database.

\subsubsection{Moderating variables.}

The strength of a country's commercial financial system was operationalized using the GEM National Expert Survey (NES) dataset (Hechavarría \& Ingram, 2018). We provide the set of questions used for developing this index in the appendix. This measure captured the availability of funding from different commercial sources, such as equity, debt, private investors, venture capitalists, and IPO for entrepreneurs in the country. The Cronbach alpha for this measure is 0.90 (Reynolds et al., 2005).

As mentioned in the hypotheses, social entrepreneurs rely not just on commercial sources of finance such as banks and venture capitalists, but also on charity- or philanthropybased investment (Dees, 2012). To capture the philanthropy-oriented financial system, we used the data relating to charity contributions (\%) made by people in different countries, provided by the World Giving Report (Charities Aid Foundation, 2017).

We operationalized the level of country's educational system using the education index provided as part of the United National Human Development Index (HDI) (United Nations Development Programme, 2015). This education index is developed by combining the mean number of years of schooling for adults aged 25 years or older along with expected years of schooling for children of school-entering age. Prior research has identified this as an appropriate measure of educational system existing in a country (Cullen, Johnson, \& Parboteeah, 2014; Parboteeah \& Cullen, 2003). 
Following prior research, we operationalized the political system of different countries in terms of the rule of law (Estrin et al., 2016; Levie \& Autio, 2011). We obtained the data relating to this from the World Governance Indicators developed by the World Bank. As a robustness check, we also considered the index of regulatory quality provided by the World Bank (Bjørnskov \& Foss, 2013; LiPuma, Newbert, \& Doh, 2013).

\subsubsection{Control variables.}

Consistent with prior research that uses multilevel analysis (Autio \& Acs, 2010; De Clercq et al., 2013), we included control variables that operate at either individual or country level. At the individual level, we control for gender (Elam \& Terjesen, 2010; Minniti \& Nardone, 2007; Verheul, Stel, \& Thurik, 2006) measured as a dummy variable ( $0=$ female; $1=$ male $)$; age measured as a continuous variable (Autio \& Acs, 2010); and work status, which captures whether the respondent is not working, is retired, or is a student $(=0)$ or working full- or parttime (=1) (Arenius \& Minniti, 2005). We also controlled for fear of failure, which is operationalized as a dummy variable equal to 1 in cases where individuals indicated that fear of failure would prevent them from starting a business, and 0 otherwise (Hessels, Grilo, Thurik, van der Zwan, \& Zwan, 2010).

Rates of entrepreneurship vary with levels of development (Autio \& Acs, 2010; De Clercq et al., 2013). Consistent with prior literature, we control for per capita GDP, the growth rate of GDP, unemployment, and government spending (as ratio of GDP) (Aidis, Estrin, \& Mickiewicz, 2010; Autio \& Acs, 2010; De Clercq et al., 2013; Estrin et al., 2016). We obtain the data for government spending (as ratio of GDP) from the Heritage Foundation, and that for the others from the World Bank. We consider a one-year lag for all these variables. Further, while testing for the contingent effects of institutional context variables on individual social entrepreneurship entry, we control for their respective country-level means. 


\subsection{Estimation}

To test our hypotheses, we conducted a multilevel logit regression analysis on this dataset for the year 2009. Since our individual-level data are nested within country-level data, we used the multilevel logit regression modelling technique (Guo \& Zhao, 2000). The use of a multilevel model offers the following advantages. Firstly, it does not ignore the interdependency between individual- and country-level data. Ignoring such interdependency can lead to biased results in coefficients, standard errors, and confidence intervals (Autio \& Acs, 2010; Hofmann, 1997), because observations within groups (i.e., countries) are correlated and thus not independently distributed. Secondly, multilevel models can provide a systematic analysis of the effects of variables that operate at multiple levels, as well as of their cross-level interactions (Echambadi, Campbell, \& Agarwal, 2006; Guo \& Zhao, 2000). Studies that focus solely on either the individual-level or country-level effects on entrepreneurship cannot make accurate inferences about the dependence of entrepreneurial decisions owing to ecological fallacy ${ }^{4}$ concerns (Terjesen et al., 2016). Our statistical approach is consistent with that followed in other multilevel entrepreneurship studies (Autio \& Acs, 2010; De Clercq et al., 2013).

Further, while testing the interaction effects, the direction of the interaction term and its statistical significance may vary for different values of the independent variable (Hoetker, 2007; Zelner, 2009). Therefore, we plot the interaction results as marginal plots between high and low values of moderator variable for different values of independent variable (Zelner, 2009).

\footnotetext{
${ }^{4}$ Ecological fallacy concerns arise when claims about individual behaviors are based on aggregated data (Robinson 1950).
} 


\section{Results}

We provide the descriptive statistics and correlation matrix in Table 1. The variance inflation factors are below the cut-off value of 4 , and thus multicollinearity is not a matter of concern in our analysis (Neter, Kutner, Nachtsheim, \& Wasserman, 1996). We calculated six logit regression models to test our hypotheses, as shown in Table 2. Model 1 includes the control variables and Model 2 adds financial capital, specific human capital and social capital to test hypotheses 1a, 1b and 1c. Models 3-6 include the interaction effects with formal institutions in a stepwise manner.

We hypothesized a positive relationship between financial capital and social entrepreneurship entry in Hypothesis 1a. We find support for this in Model $2(\beta=0.08, p<$ 0.01). Similarly, from Model 2, we also observe that there is a significant positive effect of specific human capital and social entrepreneurship entry $(\beta=0.67, p<0.001)$, lending support to Hypothesis 1b. Furthermore, we find support for Hypothesis 1c, as individual social capital has a positive and significant effect on social entrepreneurship entry $(\beta=0.71, p<0.001)$. From Model 3, we note that the interaction effect between financial capital and commercial financial system is insignificant, indicating a lack of support for our Hypothesis 2a. However, from Model 4, we find a significant positive interaction between financial capital and philanthropy-oriented financial system $(\beta=0.11, \mathrm{p}<0.01)$. This offers support to Hypothesis 2b. In Model 5, we observe that educational system has a significant positive interaction effect for specific human capital $(\beta=0.27, \mathrm{p}<0.001)$, providing support to Hypothesis 3 . Finally, in Model 6, we find a significant positive moderating effect of political system on both financial $(\beta=0.07, p<0.05)$ and specific human $(\beta=0.18, p<0.001)$ capital. Thus, we find support for Hypotheses $4 \mathrm{a}$ and $4 \mathrm{~b}$. However, there is an insignificant moderating effect for political system on the relationship between individual social capital and social entrepreneurship entry. Hence, 
we do not find support for Hypothesis 4c. We plot the graphs for significant interaction effects in Figures 2-5.

Insert Tables 1-2, Figures 2-5 about here

\subsection{Robustness tests}

We conducted multiple robustness checks, which lend greater confidence to our results. ${ }^{5}$ First, we repeated all the analysis by removing certain country-level controls such as unemployment rate and government spending separately. The results remained consistent in both instances. Second, we considered an alternative measure for political system and repeated all the analysis. We used the regulatory quality index from the World Bank and observed that our results were similar.

\section{Discussion}

In this study, we investigated the role of individual capital in social entrepreneurship entry along with the contingent effect of formal institutional context on this relationship. Drawing on capital theory, we confirm that individual capital resourcefulness enhances the likelihood of entry into social entrepreneurship. More importantly, upon integrating with institutional theory arguments, we find that this likelihood of entry is better understood when viewed as a multilevel interaction of individual capital situated within the formal institutional context.

\subsection{Theoretical contributions}

We make multiple theoretical contributions through this study. Firstly, we extend the research on individual capital and entrepreneurship (Marvel et al., 2016; Stam et al., 2014; Terjesen et al., 2016; Unger et al., 2011), by exploring the effect of individual capital on social entrepreneurship entry. Our results indicate that the possession of different forms of individual

\footnotetext{
${ }^{5}$ The results are available from the authors upon request.
} 
capital (namely, financial, human and social capital) increases the likelihood of social enterprise entry (H1a, H1b and $\mathrm{H} 1 \mathrm{c})$. This signifies the importance of resourcefulness at the individual level for engagement in social entrepreneurship activity.

Secondly, we contextualize the effect of individual capital on social entrepreneurship entry by integrating capital theory with institutional theory. We thereby contribute to the theoretical discussion around how individual capital and institutional conditions jointly influence entrepreneurship entry (De Clercq et al., 2013; Estrin et al., 2016; Huggins, Prokop, \& Thompson, 2017; Stephan et al., 2016; Terjesen et al., 2016) with a specific focus on social entrepreneurship. By employing a multilevel approach, we highlight that formal institutional context acts as a critical contingency on the relationship between individual capital and social entrepreneurship entry.

With regard to the financial system, we find that commercial financial systems and philanthropy-oriented financial systems have varied effects on the investment of individual financial capital in social entrepreneurship entry. We observe that commercial financial systems have an insignificant effect on the relationship between individual financial capital and social entrepreneurship entry (H2a). However, in countries with philanthropy-oriented financial systems, there is impetus for investment of financial capital in social entrepreneurship entry $(\mathrm{H} 2 \mathrm{~b})$. This implies that the presence of socially minded investors, rather than commercially minded investors, is critical for supporting individual financial capital investment in social entrepreneurship entry (e.g. Block et al., 2018; Sahasranamam \& Ball, 2018; Scarlata \& Alemany, 2010). This finding conforms with the cognitive argument that social enterprises are considered more legitimate by philanthropic financial systems, given their exposure to the social sector (e.g. through NGOs, foundations), unlike commercial financial systems (Islam et al., 2018; Suchman, 1995). It also resonates with our earlier citation 
of arguments from the social capital literature (Woolcock, 1998) on exclusionary norms favoring a specific form of entrepreneurship.

Moreover, we find that the educational system of a country has a positive contingent effect on the investment of entrepreneurship-specific human capital in social entrepreneurship entry (H3). This suggests that general educational standards within a country play an important complementary role alongside entrepreneurship-specific skills when it comes to entry into social entrepreneurship. We believe that this can be attributed to the normative environment that general education inculcates in terms of spirit of volunteerism and pro-social motivations (Astin et al., 2002; Forbes \& Zampelli, 2014; Grimes et al., 2013).

Our results suggest that institutional support from the government provides impetus to investment of human and financial capital in social entrepreneurship entry (H4a and H4b). However, the contingent effect is insignificant in the case of investment of social capital ( $\mathrm{H} 4 \mathrm{c})$. The suggests that individual-level resourcefulness in terms of human and financial capital helps to send out a better signal (Gimmon \& Levie, 2010) to attract support from the political system. This could be because human and financial capital are immediately and directly convertible into economic capital, unlike social capital that is dependent on complex factors requiring greater transformation to be converted into economic capital (Bourdieu, 1986). Therefore, from a regulatory viewpoint, human capital and financial capital are more likely to be expropriated in weak rule of law contexts (Autio \& Acs, 2010; Estrin et al., 2016; Sahasranamam \& Raman, 2018). Our evidence confirming the supportive role of political system is consistent with the claims that government and social enterprises act as natural partners in tackling societal issues (Santos, 2012; Sud et al., 2009). It also reiterates the need for tangible and intangible forms of support from the government to establish pragmatic legitimacy for the organizational form and to enable external resource support (Estrin et al., 2016; Sahasranamam \& Ball, 2018; Stephan et al., 2015). 
Thirdly, we add to literature comparing social and commercial entrepreneurship (Austin et al., 2006; Bacq et al., 2013; Dacin et al., 2010; Estrin et al., 2016), by identifying the similarities and differences between our results and existing research on commercial entrepreneurship. Our findings about the positive effect of individual capital on the likelihood of social entrepreneurship entry is similar to that in commercial entrepreneurship (Boudreaux \& Nikolaev, 2018; De Clercq et al., 2013; Xavier-Oliveira et al., 2015). This suggests that entry into social entrepreneurship is also a choice involving significant opportunity cost in terms of investments of individual capital.

The insignificant result for the contingent effect of commercial financial system on social entrepreneurship diverges from those of the commercial entrepreneurship literature, where a beneficial effect has been observed (Gimmon \& Levie, 2010; Ko \& McKelvie, 2018). This highlights how differences in the nature of return on investment (social return as opposed to financial) can lead to differences in external finance support. This aligns well with our earlier claim of the potential presence of strong exclusionary norms around investment of financial capital in social entrepreneurship entry within countries where commercial financial systems are better developed (Bridgstock et al., 2010; Waldinger, 1995; Woolcock, 1998).

The beneficial effect of educational system on investment of specific human capital in social entrepreneurship entry corresponds with results observed in the case of commercial entrepreneurship (De Clercq et al., 2013; Marvel et al., 2016). This suggests the complementary role of general educational quality and entrepreneurship-specific skills for both forms of entrepreneurship. Similarly, the positive contingent effect of political system on investment of human and financial capital is observed in commercial entrepreneurship too (Boudreaux \& Nikolaev, 2018; Estrin et al., 2016). The insignificant moderating effect on social capital is however different from the positive moderating effect observed in commercial entrepreneurship for related proxies of political system (Boudreaux \& Nikolaev, 2018; Stam et 
al., 2014). In summary, we can conclude that the nature of financial system (commercial vs. philanthropic) has a distinguishing effect on investment of individual capital in the two forms of entrepreneurship, while educational and political systems exhibit similar contingent effects.

\subsection{Practical implications}

The understanding of the extent and nature of the influence that various formal institutions have on social entrepreneurship is helpful in framing better policies for the development of social enterprises. Firstly, policy-makers need to pay due attention to the philanthropy orientation of their financial systems (rather than commercial orientation) to encourage individuals to invest their financial capital towards social enterprise. This could entail offering tax incentives and other benefits to philanthropic and charitable donors. Secondly, improving educational standards is key for supporting the investment of individual human capital in social entrepreneurship owing to potential inculcation of pro-social motivations through education. Thirdly, given the significance of institutional support from the political system, policy-makers need to put in place legislations that enhance the legitimacy of social enterprise as an organizational form (e.g., Benefit corporations (Miller-Stevens, Taylor, Morris, \& Lanivich, 2018)) and promulgate legislation that would offer resource support (e.g., the mandatory CSR policy in India (Agrawal \& Sahasranamam, 2016)).

\section{Limitations, future research and conclusion}

While our study enhances the understanding of institutional influence on social entrepreneurship, we acknowledge that it is not without limitations. The relationships we examine are cross-sectional in nature, and this restricts us from making causal inferences. Future research using longitudinal research designs that span a longer period could unpack the dynamic relationships between individual capital and social enterprise. For instance, researchers could examine the combined role of individual capital and institutional context on 
social entrepreneurship across phases (nascent, new and established) (Bergmann \& Stephan, 2012; Mickiewicz et al., 2017). Furthermore, given the differential effect of commercial and philanthropy-oriented financial systems that we observe, future research needs to consider different categories of external finance such as debt, equity, grants, social venture funds, and crowdfunding (refer Block et al., 2018 for a detailed list) separately, and study both its direct and contingent effects on social entrepreneurship. Considering the insignificant moderating effect of political system on investment of social capital in social entrepreneurship entry, scholars could undertake a nuanced effort exploring the contingent effects on the relationship between different forms of social capital (such as bonding and bridging social capital) and social entrepreneurship entry (Davidsson \& Honig, 2003; Stam et al., 2014). Our research considers only the contingent role of formal institutions; future research needs to explore the role of informal institutions such as culture in greater detail (e.g. (Hechavarría, 2016; Hechavarría et al., 2017)). The use of single-item constructs to operationalize individual capital is a data limitation of the study. Similarly, owing to data limitations, we are only able to explore social enterprise entry intention and not actual entry. However, given the lack of alternate largescale databases on social entrepreneurship (Lee, Battilana, \& Wang, 2014; Lepoutre et al., 2013), the GEM database with these inherent data limitations was the best suited for the research question of interest to us. Our research was focused on the role of formal institutions at the national level, but we know that institutional characteristics could vary between subnational regions (Huggins et al., 2017; Naudé, Gries, Wood, \& Meintjies, 2008). Hence, future research could explore the role of sub-national institutions on social entrepreneurship. There is also need for greater quantitative research to study how social entrepreneurship emerges and thrives in contexts of formal institutional voids (Chatterjee \& Sahasranamam, 2018; Mair, Martí, \& Ventresca, 2012). Despite these limitations, our study does provide an understanding 
of how individual capital and formal institutional context interact to influence social entrepreneurship entry.

To conclude, our study is among a handful of initial studies seeking to explain the emergence of a social enterprise as an outcome of the interplay between individual- and country-level factors. We extend capital theory to social entrepreneurship to highlight the importance of individual capital - financial, human and social - for setting up social enterprises. Furthermore, we find that the extent to which individual capital availability enhances social enterprise entry depends significantly on the formal institutional context in which it occurs.

\section{Appendix}

\section{Financial system questions from the GEM NES survey}

1. In my country, there is sufficient equity funding available for new and growing firms

2. In my country, there is sufficient debt funding available for new and growing firms

3. In my country, there are sufficient government subsidies available for new and growing firms

4. In my country, there is sufficient funding available from private individuals (other than founders) for new and growing firms

5. In my country, there is sufficient venture capitalist funding available for new and growing firms.

6. In my country, there is sufficient funding available through initial public offerings (IPOs) for new and growing firms

\section{References}

Agarwal, N., Chakrabarti, R., Brem, A., \& Bocken, N. (2018). Market driving at Bottom of the Pyramid (BoP): An analysis of social enterprises from the healthcare sector. Journal of Business Research, 86(May), 234-244.

Agrawal, A., \& Sahasranamam, S. (2016). Corporate social entrepreneurship in India. South Asian Journal of Global Business Research, 5(2), 214-233.

Aidis, R., Estrin, S., \& Mickiewicz, T. M. (2010). Size matters: Entrepreneurial entry and government. Small Business Economics, 39(1), 119-139.

Amorós, J. E., \& Bosma, N. (2013). Global Entrepreneurship Monitor (GEM) 2013 global report. London: Global Entrepreneurship Research Association.

Aragon-Mendoza, J., del Val, M. P., \& Roig-Dobón, S. (2016). The influence of institutions development in venture creation decision: A cognitive view. Journal of Business Research, 69(11), 4941-4946. 
Arenius, P., \& Minniti, M. (2005). Perceptual variables and nascent entrepreneurship. Small Business Economics, 24(3), 233-247.

Arthurs, J. D., Busenitz, L. W., Hoskisson, R. E., \& Johnson, R. A. (2009). Signaling and initial public offerings: The use and impact of the lockup period. Journal of Business Venturing, 24(4), 360-372.

Astin, A. W., Keup, J. R., \& Lindholm, J. A. (2002). A decade of changes in undergraduate education: A national study of system "transformation." The Review of Higher Education, 25(2), 141-162.

Austin, J., Stevenson, H., \& Wei-skillern, J. (2006). Social and commercial entrepreneurship: Same, different, or both? Entrepreneurship Theory and Practice, 30(1), 1-22.

Autio, E., \& Acs, Z. J. (2010). Intellectual property protection and the formation of entrepreneurial growth aspirations. Strategic Entrepreneurship Journal, 4(4), 234-251.

Autio, E., Pathak, S., \& Wennberg, K. (2013). Consequences of cultural practices for entrepreneurial behaviors. Journal of International Business Studies, 44(4), 334-362.

Bacchiega, A., \& Borzaga, C. (2001). Social enterprises as incentive structures: An economic analysis. In C. Borzaga \& J. Defourny (Eds.), The Emergence of Social Enterprise (pp. 273-294). London: Routledge.

Bacq, S., Hartog, C., \& Hoogendoorn, B. (2013). A quantitative comparison of social and commercial entrepreneurship: Toward a more nuanced understanding of social entrepreneurship organizations in context. Journal of Social Entrepreneurship, 4(1), 4068.

Bacq, S., Hartog, C., \& Hoogendoorn, B. (2016). Beyond the moral portrayal of social entrepreneurs: An empirical approach to who they are and what drives them. Journal of Business Ethics, 133(4), 703-718.

Bacq, S., \& Janssen, F. (2011). The multiple faces of social entrepreneurship: A review of definitional issues based on geographical and thematic criteria. Entrepreneurship \& Regional Development, 23(5-6), 373-403.

Baker, T., Gedajlovic, E., \& Lubatkin, M. (2005). A framework for comparing entrepreneurship processes across nations. Journal of International Business Studies, 36(5), 492-504.

Baker, W. (1990). Market networks and corporate behavior. American Journal of Sociology, 96(3), 589-625.

Battilana, J., \& Dorado, S. (2010). Building sustainable hybrid organizations: The case of commercial microfinance organizations. Academy of Management Journal, 53(6), 14191440.

Battilana, J., \& Lee, M. (2014). Advancing research on hybrid organizing - Insights from the study of social enterprises. The Academy of Management Annals, 8(1), 397-441.

Baumol, W. J. (1990). Entrepreneurship: Productive, unproductive, and destructive. Journal of Political Economy, 98(5), 893-921.

Becker, G. S. (1994). Human capital: A theoretical and empirical analysis with specific reference to education. Chicago: University of Chicago Press.

Begley, T., Tan, W., \& Schoch, H. (2005). Politico-economic factors associated with interest in starting a business: A multi-country study. Entrepreneurship Theory and Practice, 29(1), 35-55.

Bergmann, H., \& Stephan, U. (2012). Moving on from nascent entrepreneurship: measuring cross-national differences in the transition to new business ownership. Small Business Economics, 41(4), 945-959.

Beynon, M. J., Jones, P., \& Pickernell, D. (2018). Entrepreneurial climate and selfperceptions about entrepreneurship: A country comparison using fsQCA with dual outcomes. Journal of Business Research., 89(August), 418-428. 
Bhagavatula, S., Elfring, T., van Tilburg, A., \& van de Bunt, G. G. (2010). How social and human capital influence opportunity recognition and resource mobilization in India's handloom industry. Journal of Business Venturing, 25(3), 245-260.

Bjørnskov, C., \& Foss, N. (2013). How strategic entrepreneurship and the institutional context drive economic growth. Strategic Entrepreneurship Journal, 7(1), 50-69.

Blanchflower, D. G., \& Oswald, A. (1998). What makes an entrepreneur? Journal of Labour Economics, 16(1), 26-60.

Block, J. H., Colombo, M. G., Cumming, D. J., \& Vismara, S. (2018). New players in entrepreneurial finance and why they are there. Small Business Economics, 50(2), 239250.

Boudreaux, C. J., \& Nikolaev, B. (2018). Capital is not enough: Opportunity entrepreneurship and formal institutions. Small Business Economics, forthcomin.

Bourdieu, P. (1986). The forms of capital. In J. Richardson (Ed.), Handbook of Theory and Research for the Sociology of Education (pp. 241-258). Westport: Greenwood.

Bowen, H. P., \& De Clercq, D. (2008). Institutional context and the allocation of entrepreneurial effort. Journal of International Business Studies, 39(4), 747-768.

Bridgstock, R., Lettice, F., Özbilgin, M. F., \& Tatli, A. (2010). Diversity management for innovation in social enterprises in the UK. Entrepreneurship \& Regional Development, 22(6), 557-574.

Bull, M. (2018). Reconceptualising social enterprise in the UK through an appreciation of legal identities. International Journal of Entrepreneurial Behavior \& Research, 24(3), 587-605.

Burt, R. (1997). The contingent value of social capital. Administrative Science Quarterly, 42(2), 339-365.

Burt, R. S. (1992). Structural holes: The social structure of competition. Cambridge: Harvard University Press.

Cai, L., Hughes, M., \& Yin, M. (2014). The relationship between resource acquisition methods and firm performance in Chinese new ventures: The intermediate effect of learning capability. Journal of Small Business Management, 52(3), 365-389.

Caputo, R. K., \& Dolinsky, A. (1998). Women's choice to pursue self-employment: The role of financial and human capital of household members. Journal of Small Business Management, 36(3), 8-17.

Casson, M. (1982). The entrepreneur. Totowa, New Jersey: Barnes \& Noble books.

Cetindamar, D., Gupta, V. K., Karadeniz, E. E., \& Egrican, N. (2012). What the numbers tell: The impact of human, family and financial capital on women and men's entry into entrepreneurship in Turkey. Entrepreneurship \& Regional Development, 24(1-2), 2951.

Charities Aid Foundation. (2017). World Giving Report. Retrieved from https://www.cafonline.org/about-us/publications/2017-publications/caf-world-givingindex-2017

Chatterjee, D., \& Sahasranamam, S. (2018). Technological innovation research in China and India: A bibliometric analysis for the period 1991-2015. Management and Organization Review, 14(1), 179-221.

Churchill, N. C., \& Bygrave, W. D. (1990). The entrepreneurship paradigm (II): Chaos and catastrophes among quantum jumps? Entrepreneurship Theory and Practice, 14(2), 7 30.

Coleman, J. (1988). Social capital in the creation of human capital. American Journal of Sociology, 94, S95-S120.

Cooper, A. C., Gimeno-Gascon, F. J., \& Woo, C. Y. (1994). Initial human and financial capital as predictors of new venture performance. Journal of Business Venturing, 9(5), 
371-395.

Costanzo, L. A., Vurro, C., Foster, D., Servato, F., \& Perrini, F. (2014). Dual-mission management in social entrepreneurship: Qualitative evidence from social firms in the United Kingdom. Journal of Small Business Management, 52(4), 655-677.

Cullen, J. B., Johnson, J. L., \& Parboteeah, K. P. (2014). National rates of opportunity entrepreneurship activity: Insights from institutional anomie theory. Entrepreneurship Theory and Practice, 38(4), 775-806.

Dacin, P. A., Dacin, T. M., \& Matear, M. (2010). Social entrepreneurship: Why we don't need a new theory and how we move forward from here. Academy of Management Perspectives, 24(3), 37-57.

Dana, L. P., \& Light, I. (2011). Two forms of community entrepreneurship in Finland: Are there differences between Finnish and Sámi reindeer husbandry entrepreneurs? Entrepreneurship \& Regional Development, 23(5-6), 331-352.

Dart, R. (2004). The legitimacy of social enterprise. Nonprofit and Voluntary Sector Quarterly, 14(4), 411-424.

Davidsson, P., \& Honig, B. (2003). The role of social and human capital among nascent entrepreneurs. Journal of Business Venturing, 18(3), 301-331.

Davidsson, P., \& Wiklund, J. (2001). Levels of analysis in entrepreneurship research: Current research practice and suggestions for the future. Entrepreneurship Theory and Practice, 25(4), 81-100.

De Clercq, D., \& Arenius, P. (2006). The role of knowledge in business start-up activity. International Small Business Journal, 24(4), 339-358.

De Clercq, D., Lim, D. S. K., \& Oh, C. H. (2013). Individual-level resources and new business activity: The contingent role of institutional context. Entrepreneurship Theory and Practice, 37(2), 303-330.

Dees, J. G. (1998). Enterprising nonprofits. Harvard Business Review, 76(1), 54-67.

Dees, J. G. (2012). A tale of two cultures: Charity, problem solving, and the future of social entrepreneurship. Journal of Business Ethics, 111(3), 321-334.

Desa, G. (2012). Resource mobilization in international social entrepreneurship: Bricolage as a mechanism of institutional transformation. Entrepreneurship Theory and Practice, 36(4), 727-751.

Desa, G., \& Basu, S. (2013). Optimization or bricolage? Overcoming resource contraints in global social entrepreneurship. Strategic Entrepreneurship Journal, 7(1), 26-49.

Dheer, R. J. S. (2017). Cross-national differences in entrepreneurial activity: role of culture and institutional factors. Small Business Economics, 48(4), 813-842.

DiMaggio, P. J., \& Powell, W. W. (1991). The new institutionalism in organizational analysis. Chicago, IL: University of Chicago Press.

Djankov, S., Porta, R. La, Lopez-De-Silanes, F., \& Shleifer, A. (2002). The regulation of entry. Quarterly Journal of Economics, CXVII(1), 1-37.

Dollinger, M. J. (1995). Entrepreneurship: Strategies and resources. Boston, MA: Prentice Hall.

Echambadi, R., Campbell, B., \& Agarwal, R. (2006). Encouraging best practice in quantitative management research: An incomplete list of opportunities. Journal of Management Studies, 43(8), 1801-1820.

Elam, A., \& Terjesen, S. (2010). Gender and development. European Journal of Development Research, 22(3), 331-348.

Estrin, S., \& Mickiewicz, T. (2011). Institutions and female entrepreneurship. Small Business Economics, 37(4), 397-415.

Estrin, S., Mickiewicz, T., \& Stephan, U. (2013). Entrepreneurship, social capital, and institutions: Social and commercial entrepreneurship across nations. Entrepreneurship 
Theory and Practice, 37(3), 479-504.

Estrin, S., Mickiewicz, T., \& Stephan, U. (2016). Human capital in social and commercial entrepreneurship. Journal of Business Venturing, 31(4), 449-467.

Evans, P. (1996). Government action, social capital and development: Reviewing the evidence on synergy. World Development, 24(6), 1119-1132.

Forbes, K. F., \& Zampelli, E. M. (2014). Volunteerism: The influences of social, religious, and human capital. Nonprofit and Voluntary Sector Quarterly, 43(2), 227-253.

Gedajlovic, E., Honig, B., Moore, C. B., Payne, G. T., \& Wright, M. (2013). Social capital and entrepreneurship: A schema and research agenda. Entrepreneurship Theory and Practice, 37(3), 455-478.

Gimmon, E., \& Levie, J. (2010). Founder's human capital, external investment, and the survival of new high-technology ventures. Research Policy, 39(9), 1214-1226.

Global Entrepreneurship Monitor. (2009). GEM 2009 adult population survey questionnaire.

Goltz, S., Buche, M. W., \& Pathak, S. (2015). Political empowerment, rule of law, and women's entry into entrepreneurship. Journal of Small Business Management, 53(3), 605-626.

Granovetter, M. (1985). Economic action and social structure: The problem of embeddedness. American Journal of Sociology, 91(3), 481-510.

Gras, D., \& Lumpkin, G. T. (2012). Strategic Foci in Social and Commercial Entrepreneurship: A Comparative Analysis. Journal of Social Entrepreneurship, 3(1), 6-23.

Grichnik, D., Brinckmann, J., Singh, L., \& Manigart, S. (2014). Beyond environmental scarcity: Human and social capital as driving forces of bootstrapping activities. Journal of Business Venturing, 29(2), 310-326.

Grimes, M. G., McMullen, J. S., Vogus, T. J., \& Miller, T. L. (2013). Studying the origins of social entrepreneurship: Compassion and the role of embedded agency. Academy of Management Review, 38(3), 460-463.

Guo, G., \& Zhao, H. (2000). Multilevel modeling for binary data. Annual Review of Sociology, 26, 441-462.

Haigh, N., Kennedy, E. D., \& Walker, J. (2015). Hybrid organizations as shape-shifters: Altering legal structure for strategic gain. California Management Review, 57(3), 59-82.

Harding, R. (2006). Social entrepreneurship monitor United Kingdom 2006. London.

Harding, R., \& Cowling, M. (2004). The GEM UK social entrepreneurship monitor. London: Global Entrepreneurship Research Association.

Haugh, H. (2007). Community-led social venture creation. Entrepreneurship Theory and Practice, 31(2), 161-183.

Hechavarría, D. M. (2016). The impact of culture on national prevalence rates of social and commercial entrepreneurship. International Entrepreneurship and Management Journal, 12(4), 1025-1052.

Hechavarría, D. M., \& Ingram, A. E. (2018). Entrepreneurial ecosystem conditions and gendered national-level entrepreneurial activity : A 14-year panel study of GEM. Small Business Economics, forthcomin.

Hechavarria, D. M., Ingram, A., Justo, R., \& Terjesen, S. (2012). Are women more likely to pursue social and environmental entrepreneurship? Global Women's Entrepreneurship Research: Diverse Settings, Questions and Approaches, 135-151.

Hechavarría, D. M., Terjesen, S. A., Ingram, A. E., Renko, M., Justo, R., \& Elam, A. (2017). Taking care of business: The impact of culture and gender on entrepreneurs' blended value creation goals. Small Business Economics, 48(1), 225-257.

Henderson, F., Reilly, C., Moyes, D., \& Whittam, G. (2018). From charity to social enterprise: The marketization of social care. International Journal of Entrepreneurial 
Behavior \& Research, 24(3), 651-666.

Hessels, J., Grilo, I., Thurik, R., van der Zwan, P., \& Zwan, P. (2010). Entrepreneurial exit and entrepreneurial engagement. Journal of Evolutionary Economics, 21(3), 447-471.

Hoetker, G. (2007). The use of logit and probit models in strategic management research: Critical issues. Strategic Management Journal, 28(4), 331-343.

Hofer, C. W., \& Schendel, D. E. (1978). Strategy formulation: Analysis and concepts. St. Paul, MN: West Publishing.

Hofmann, D. (1997). An overview of the logic and rationale of hierarchical linear models. Journal of Management, 23(6), 723-744.

Huggins, R., Prokop, D., \& Thompson, P. (2017). Entrepreneurship and the determinants of firm survival within regions: human capital, growth motivation and locational conditions. Entrepreneurship and Regional Development, 29(3-4), 357-389.

Islam, M., Fremeth, A., \& Marcus, A. (2018). Signaling by early stage startups: US government research grants and venture capital funding. Journal of Business Venturing, $33(1), 35-51$.

Jack, S. L., \& Anderson, A. R. (2002). The effects of embeddedness on the entrepreneurial process. Journal of Business Venturing, 17(5), 467-487.

Kachlami, H., Yazdanfar, D., \& Öhman, P. (2018). Regional demand and supply factors of social entrepreneurship. International Journal of Entrepreneurial Behavior \& Research, 24(3), 714-733.

Kim, P. H., Aldrich, H. E., \& Keister, L. A. (2006). Access (not) denied: The impact of financial, human, and cultural capital on entrepreneurial entryin the United States. Small Business Economics, 27(1), 5-22.

Klyver, K., Hindle, K., \& Meyer, D. (2008). Influence of social network structure on entrepreneurship participation-A study of 20 national cultures. International Entrepreneurship and Management Journal, 4(3), 331-347.

Ko, E. J., \& McKelvie, A. (2018). Signaling for more money: The roles of founders' human capital and investor prominence in resource acquisition across different stages of firm development. Journal of Business Venturing, forthcomin.

Korosec, R. L., \& Berman, E. M. (2006). Municipal support for social entrepreneurship. Public Administration Review, 66(June), 448-462.

Kshetri, N. (2009). Entrepreneurship in post-socialist economies: A typology and institutional contexts for market entrepreneurship. Journal of International Entrepreneurship, 7(3), 236-259.

Lee, M., Battilana, J., \& Wang, T. (2014). Building an infrastructure for empirical research on social enterprise: Challenges and opportunities. In J. C. Short, D. J. Ketchen, \& D. D. Bergh (Eds.), Social Entrepreneurship and Research Methods (9th ed., pp. 241-264). Emerald Group Publishing.

Lepoutre, J., Justo, R., Terjesen, S., \& Bosma, N. (2013). Designing a global standardized methodology for measuring social entrepreneurship activity: The Global Entrepreneurship Monitor social entrepreneurship study. Small Business Economics, 40(3), 693-714.

Levie, J., \& Autio, E. (2008). A theoretical grounding and test of the GEM model. Small Business Economics, 31(3), 235-263.

Levie, J., \& Autio, E. (2011). Regulatory burden, rule of law, and entry of strategic entrepreneurs: An international panel study. Journal of Management Studies, 48(6), 1392-1419.

Levie, J., Brooksbank, D., Jones-Evans, D., Harding, R., \& Hart, M. (2006). Measuring social entrepreneurship: Lessons from three years of experimentation by the UK Global Entrepreneurship Monitor team. In Babson College Entrepreneurship Research 


\section{Conference.}

LiPuma, J. a., Newbert, S. L., \& Doh, J. P. (2013). The effect of institutional quality on firm export performance in emerging economies: A contingency model of firm age and size. Small Business Economics, 40(4), 817-841.

Lumpkin, G. T., Bacq, S., \& Pidduck, R. J. (2018). Where change happens: Community-level phenomena in social entrepreneurship research. Journal of Small Business Management, 56(1), 24-50.

Mair, J., \& Marti, I. (2009). Entrepreneurship in and around institutional voids: A case study from Bangladesh. Journal of Business Venturing, 24(5), 419-435.

Mair, J., \& Martí, I. (2006). Social entrepreneurship research: A source of explanation, prediction, and delight. Journal of World Business, 41(1), 36-44.

Mair, J., Martí, I., \& Ventresca, M. J. (2012). Building inclusive markets in rural Bangladesh: How intermediaries work institutional voids. Academy of Management Journal, 55(4), 819-850.

Manolova, T. S., Carter, N. M., Manev, I. M., \& Gyoshev, B. S. (2007). The differential effect of men and women entrepreneurs' human capital and networking on growth expectancies in Bulgaria. Entrepreneurship Theory and Practice, 31(3), 407-426.

Marvel, M. R., Davis, J. L., \& Sproul, C. R. (2016). Human capital and entrepreneurship research: A critical review and future directions. Entrepreneurship: Theory and Practice, 40(3), 599-626.

McKeever, E., Anderson, A., \& Jack, S. (2014). Entrepreneurship and mutuality: social capital in processes and practices. Entrepreneurship \& Regional Development, 26(5-6), 453-477.

McKnight, B., \& Zietsma, C. (2018). Finding the threshold: A configurational approach to optimal distinctiveness. Journal of Business Venturing, 33(March), 493-512.

McMullen, J. S. (2011). Delineating the domain of development entrepreneurship: A marketbased approach to facilitating inclusive economic growth. Entrepreneurship Theory and Practice, 35(1), 185-193.

McMullen, J. S., \& Dimov, D. (2013). Time and the entrepreneurial journey: The problems and promise of studying entrepreneurship as a process. Journal of Management Studies, 50(8), 1481-1512.

McMullen, J. S., \& Shepherd, D. A. (2006). Entrepreneurial action and the role of uncertainty in the theory of the entrepreneur. Academy of Management Review, 31(1), 132-152.

Meyskens, M., Carsrud, A. L., \& Cardozo, R. N. (2010). The symbiosis of entities in the social engagement network: The role of social ventures. Entrepreneurship \& Regional Development, 22(5), 425-455.

Meyskens, M., Robb-Post, C., Stamp, J. A., Carsrud, A. L., \& Reynolds, P. D. (2010). Social ventures from a resource-based perspective: An exploratory study assessing global Ashoka fellows. Entrepreneurship Theory and Practice, 34(4), 661-680.

Mickiewicz, T., Nyakudya, F. W., Theodorakopoulos, N., \& Hart, M. (2017). Resource endowment and opportunity cost effects along the stages of entrepreneurship. Small Business Economics, 48(4), 953-976.

Millar, R., \& Hall, K. (2013). Social Return on Investment (SROI) and performance measurement. Public Management Review, 15(6), 923-941.

Miller-Stevens, K., Taylor, J. A., Morris, J. C., \& Lanivich, S. E. (2018). Assessing value differences between leaders of two social venture types: Benefit corporations and nonprofit organizations. Voluntas: International Journal of Voluntary and Nonprofit Organizations, forthcomin, 1-13.

Miller, T. L., Grimes, M. G., McMullen, J. S., \& Vogus, T. J. (2012). Venturing for others with heart and head: How compassion encourages social entrepreneurship. Academy of 
Management Review, 37(4), 616-640.

Minniti, M., \& Bygrave, W. (1999). The microfoundations of entrepreneurship. Entrepreneurship Theory and Practice, 23(4), 41-52.

Minniti, M., \& Nardone, C. (2007). Being in someone else's shoes: The role of gender in nascent entrepreneurship. Small Business Economics, 28(2-3), 223-238.

Moore, M.-L., Westley, F. R., \& Nicholls, A. (2012). The social finance and social innovation nexus. Journal of Social Entrepreneurship, 3(2), 115-132.

Moss, T. W., Short, J. C., Payne, G. T., \& Lumpkin, G. T. (2011). Dual identities in social ventures: An exploratory study. Entrepreneurship Theory and Practice, 35(4), 805-830.

Mullins, D., Czischke, D., \& van Bortel, G. (2012). Exploring the meaning of hybridity and social enterprise in housing organisations. Housing Studies, 27, 405-417.

Muñoz, P., \& Kibler, E. (2016). Institutional complexity and social entrepreneurship: A fuzzy-set approach. Journal of Business Research, 69(4), 1314-1318.

Munoz, S. A., \& Tindsley, S. (2008). Selling to the public sector - Prospects and problems for social enterprise in the UK. Journal of Corporate Citizenship, 32, 43-62.

Nahapiet, J., \& Ghoshal, S. (1998). Social capital, intellectual capital and the organizational advantage. Academy of Management Review, 23(2), 242-266.

Naudé, W., Gries, T., Wood, E., \& Meintjies, A. (2008). Regional determinants of entrepreneurial start-ups in a developing country. Entrepreneurship \& Regional Development, 20(2), 111-124.

Neter, J., Kutner, M. H., Nachtsheim, C. J., \& Wasserman, W. (1996). Applied linear statistical models (4th ed.). Boston: Irwin.

Nicholls, A. (2008). Social entrepreneurship: New models of sustainable social change. Oxford: Oxford University Press.

Nicholls, A. (2010). The institutionalization of social investment: The interplay of investment logics and investor rationalities. Journal of Social Entrepreneurship, 1(1), 70-100.

North, D. C. (1990). Institutions, institutional change and economic performance. Cambridge University Press.

Parboteeah, K. P., \& Cullen, J. B. (2003). Social institutions and work centrality: Explorations beyond national culture. Organization Science, 14(2), 137-148.

Pathak, S., \& Muralidharan, E. (2016). Informal institutions and their comparative influences on social and commercial entrepreneurship: The role of in-group collectivism and interpersonal trust. Journal of Small Business Management, 54, 168-188.

Peterman, N., \& Kennedy, J. (2003). Enterprise education: Influencing students' perceptions of entrepreneurship. Entrepreneurship Theory and Practice, 28(2), 129-144.

Putnam, R. (2000). Bowling alone: The collapse and revival of American community. New York: Simon and Schuster.

Rauch, A., \& Rijsdijk, S. A. (2013). The effects of general and specific human capital on long-term growth and failure of newly founded businesses. Entrepreneurship Theory \& Practice, 37(4), 923-941.

Rey-Martí, A., Ribeiro-Soriano, D., \& Sánchez-García, J. L. (2016). Giving back to society: Job creation through social entrepreneurship. Journal of Business Research, 69(6), 2067-2072.

Reynolds, P. D., Bosma, N., Autio, E., Hunt, S., De Bono, N., Servais, I., ... Chin, N. (2005). Global Entrepreneurship Monitor: Data collection design and implementation. Small Business Economics, 24(3), 205-231.

Robinson, W. S. (1950). Ecological correlations and the behavior of individuals. American Sociological Review, 15(3), 351-357.

Sahasranamam, S., \& Ball, C. (2016). Sustainable procurement in social enterprises: Comparative case studies from India and Scotland. In L. Bals \& W. Tate (Eds.), 
Implementing triple bottom line sustainability into global supply chains (pp. 219-231). Greenleaf Publishing.

Sahasranamam, S., \& Ball, C. (2018). National context matters: Influence of national business system on social enterprises in Scotland and India. In L. J. Spence, J. G. Frynas, J. N. Muthuri, \& J. Navare (Eds.), Research handbook on small business social responsibility: Global perspectives (pp. 23-46). Cheltenham: Edward Elgar Publishing Ltd.

Sahasranamam, S., \& Raman, V. (2018). Individual resources, property rights and entrepreneurship in China. International Journal of Emerging Markets, forthcomin.

Sahasranamam, S., \& Sud, M. (2016). Opportunity and necessity entrepreneurship: A comparative study of India and China. Academy of Entrepreneurship Journal, 22(1), 2140.

Sakarya, S., Bodur, M., Yildirim-Öktem, Ö., \& Selekler-Göksen, N. (2012). Social alliances: Business and social enterprise collaboration for social transformation. Journal of Business Research, 65(12), 1710-1720.

Santos, F. M. (2012). A positive theory of social entrepreneurship. Journal of Business Ethics, 111(3), 335-351.

Scarlata, M., \& Alemany, L. (2010). Deal structuring in philanthropic venture capital investments: Financing instrument, valuation and covenants. Journal of Business Ethics, 95(2), 121-145.

Schofer, E., \& Fourcade-Gourinchas, M. (2001). The structural contexts of civic engagement: Voluntary association membership in comparative perspective. American Sociological Review, 66(6), 806-828.

Scott, W. R. (2001). Crafting an Analytic Framework I. In Institutions and Organizations (2nd ed., pp. 47-70). Thousand Oaks: Sage Publications.

Shane, S., \& Venkataraman, S. (2000). The promise of entrepreneurship as a field of research. Academy of Management Review, 25(1), 217-226.

Sharir, M., \& Lerner, M. (2006). Gauging the success of social ventures initiated by individual social entrepreneurs. Journal of World Business, 41(1), 6-20.

Smith, W. K., Gonin, M., \& Besharov, M. L. (2013). Managing social-business tensions: A review and research agenda for social enterprises. Business Ethics Quarterly, 23(3), 407-442.

Stam, W., Arzlanian, S., \& Elfring, T. (2014). Social capital of entrepreneurs and small firm performance: A meta-analysis of contextual and methodological moderators. Journal of Business Venturing, 29(1), 152-173.

Stephan, U., Patterson, M., Kelly, C., \& Mair, J. (2016). Organizations driving positive social change. Journal of Management, 42(5), 1250-1281.

Stephan, U., Uhlaner, L. M., \& Stride, C. (2015). Institutions and social entrepreneurship: The role of institutional voids, institutional support, and institutional configurations. Journal of International Business Studies, 46(3), 308-331.

Subramaniam, N., Kansal, M., \& Babu, S. (2017). Governance of mandated corporate social responsibility: Evidence from Indian government-owned firms. Journal of Business Ethics, 143(3), 543-563.

Suchman, M. (1995). Managing legitimacy: Strategic and institutional approaches. Academy of Management Review, 20(3), 571-611.

Sud, M., van Sandt, C. V., \& Baugous, A. M. (2009). Social entrepreneurship: The role of institutions. Journal of Business Ethics, 85(1), 201-216.

Sunley, P., \& Pinch, S. (2012). Financing social enterprise: Social bricolage or evolutionary entrepreneurialism? Social Enterprise Journal, 8(2), 108-122.

Teasdale, S. (2010). Explaining the multifaceted nature of social enterprise: Impression 
management as (social) entrepreneurial behaviour. Voluntary Sector Review, 1(3), 271292.

Terjesen, S., Hessels, J., \& Li, D. (2016). Comparative international entrepreneurship: A review and research agenda. Journal of Management, 42(1), 299-344.

Terjesen, S., Lepoutre, J., Justo, R., \& Bosma, N. (2012). Global Entrepreneurship Monitor: Social entrepreneurship study.

Thompson, J., Alvy, G., \& Lees, A. (2000). Social entrepreneurship: A new look at the people and the potential. Management Decision, 38(5), 328-338.

Tomer, J. F. (1987). Organizational capital. New York: Praeger Press.

Unger, J., Rauch, A., Frese, M., \& Rosenbusch, N. (2011). Human capital and entrepreneurial success: A meta-analytic review. Journal of Business Venturing, 26(2), 341-385.

United Nations Development Programme. (2015). Human Development Index (HDI). Retrieved from http://hdr.undp.org/en/content/human-development-index-hdi

Van de Ven, H. (1993). The development of an infrastructure for entrepreneurship. Journal of Business Venturing, 8(3), 211-230.

Vanacker, T., Collewaert, V., \& Paeleman, I. (2013). The relationship between slack resources and the performance of entrepreneurial firms: The role of venture capital and angel investors. Journal of Management Studies, 50(6), 1070-1096.

Venkataraman, S. (1997). The distinctive domain of entrepreneurship research. In J. Katz (Ed.), Advances in Entrepreneurship, Firm Emergence and Growth (pp. 119-138). JAI Press.

Verheul, I., Stel, A. Van, \& Thurik, R. (2006). Explaining female and male entrepreneurship at the country level. Entrepreneurship \& Regional Development, 18(2), 151-183.

Viswanathan, M., \& Rosa, J. A. (2010). Understanding subsistence marketplaces: Toward sustainable consumption and commerce for a better world. Journal of Business Research, 63(6), 535-537.

Waldinger, R. (1995). The "Other Side" of embeddedness: A case study of the interplay between economy and ethnicity. Ethnic and Racial Studies, 18(3), 555-580.

Welter, F. (2011). Contextualizing entrepreneurship - Conceptual challenges and ways forward. Entrepreneurship Theory and Practice, 35(1), 165-184.

Whitley, R. (1992). European business systems: Firms and markets in their national context. London: Sage Publications.

Whitley, R. (1999). Divergent capitalisms: The social structuring and change of business systems. Oxford: Oxford University Press.

Woolcock, M. (1998). Social capital and economic development: Toward a theoretical synthesis and policy framework. Theory and Society, 27(2), 151-208.

Wright, M., Lockett, A., Clarysse, B., \& Binks, M. (2006). University spin-out companies and venture capital. Research Policy, 35(4), 481-501.

Xavier-Oliveira, E., Laplume, A. O., \& Pathak, S. (2015). What motivates entrepreneurial entry under economic inequality? The role of human and financial capital. Human Relations, 68(7), 1183-1207.

Zahra, S. A., Gedajlovic, E., Neubaum, D. O., \& Shulman, J. M. (2009). A typology of social entrepreneurs: Motives, search processes and ethical challenges. Journal of Business Venturing, 24(5), 519-532.

Zahra, S. A., \& Wright, M. (2011). Entrepreneurship's next act. Academy of Management Perspectives, 25(4), 67-83.

Zelner, B. A. (2009). Using simulation to interpret results from logit, probit, and other nonlinear models. Strategic Management Journal, 30(12), 1335-1348. 


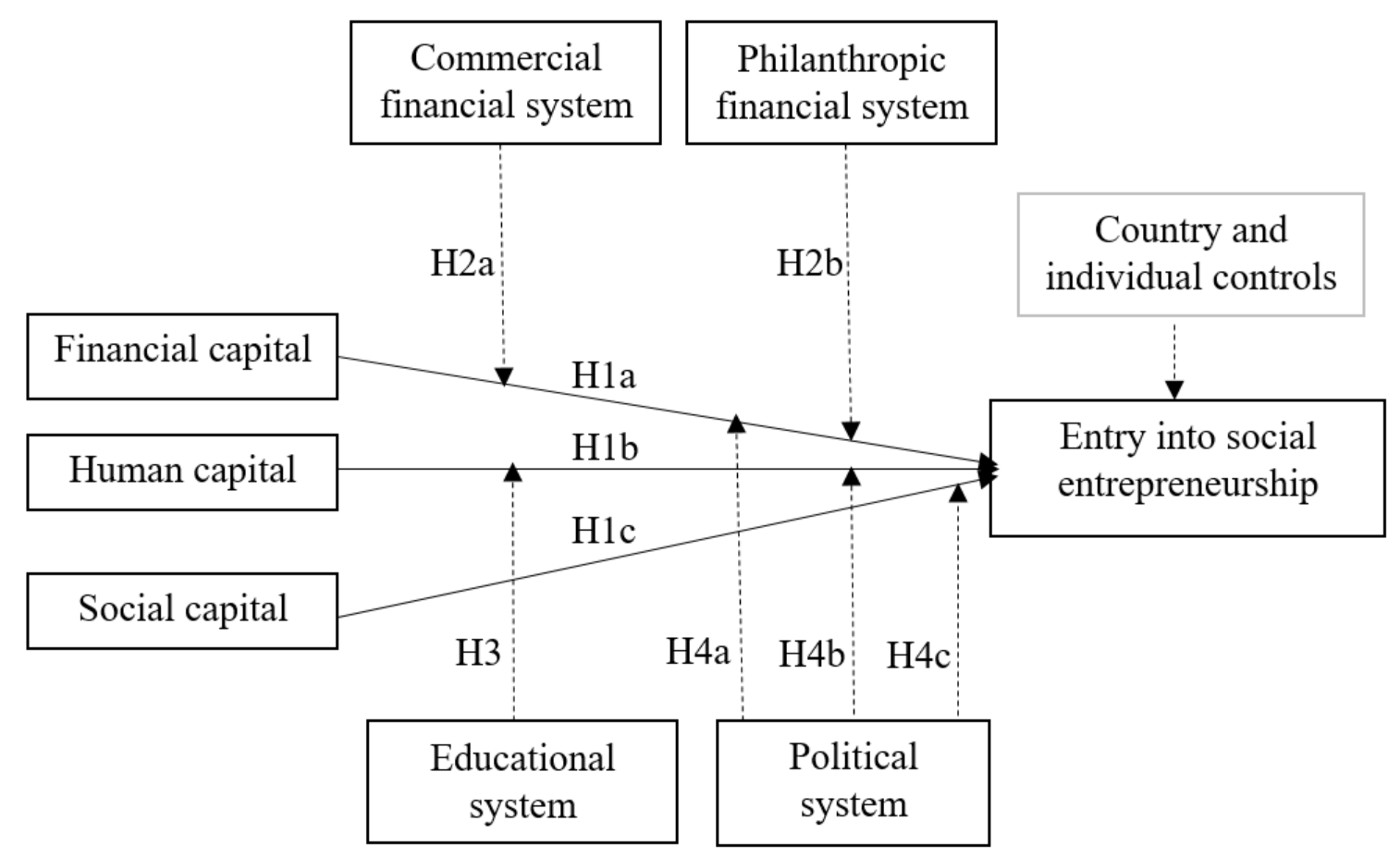

Figure 1. Conceptual framework 
Table 1. Summary statistics and correlations

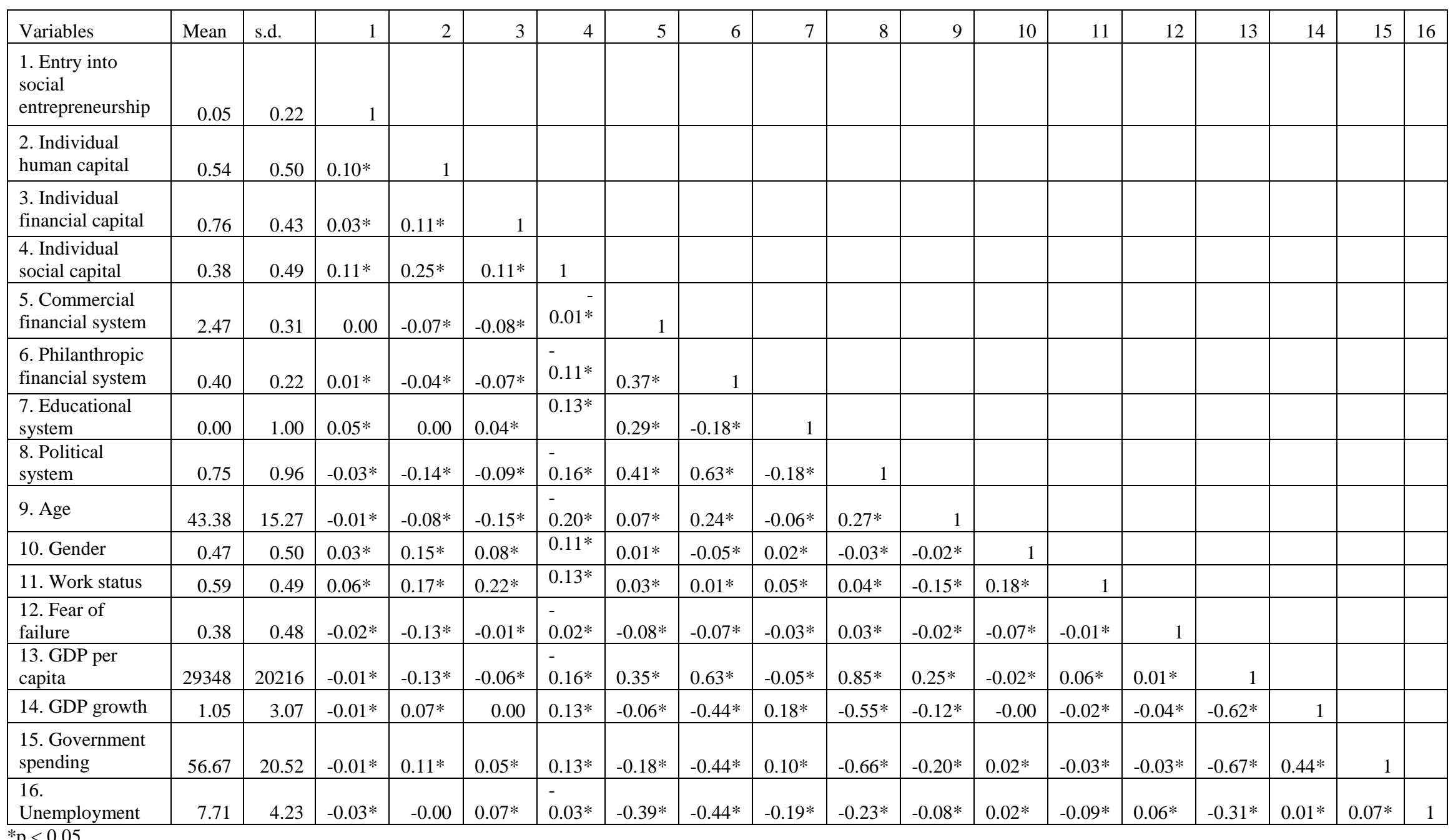


Table 2. Multilevel logit regression results

\begin{tabular}{|c|c|c|c|c|c|c|}
\hline Variables & $\begin{array}{l}\text { Model } \\
1 \\
\end{array}$ & $\begin{array}{l}\text { Model } \\
2 \\
\end{array}$ & $\begin{array}{l}\text { Model } \\
\mathbf{3} \\
\end{array}$ & $\begin{array}{l}\text { Model } \\
\mathbf{4} \\
\end{array}$ & $\begin{array}{l}\text { Model } \\
5 \\
\end{array}$ & $\begin{array}{l}\text { Model } \\
6 \\
\end{array}$ \\
\hline \multicolumn{7}{|l|}{ Controls: Individual level } \\
\hline Age & $\begin{array}{l}0.01 \\
(0.01)\end{array}$ & $\begin{array}{l}0.02 \\
(0.01)\end{array}$ & $\begin{array}{l}0.01 \\
(0.01)\end{array}$ & $\begin{array}{l}0.02 \\
(0.01)\end{array}$ & $\begin{array}{l}0.02 \\
(0.01)\end{array}$ & $\begin{array}{l}0.02 \\
(0.01)\end{array}$ \\
\hline Gender & $\begin{array}{l}0.08 \\
(0.03)\end{array}$ & $\begin{array}{l}0.01 \\
(0.03)\end{array}$ & $\begin{array}{l}0.01 \\
(0.03)\end{array}$ & $\begin{array}{l}0.01 \\
(0.03)\end{array}$ & $\begin{array}{l}0.01 \\
(0.03)\end{array}$ & $\begin{array}{l}0.01 \\
(0.03)\end{array}$ \\
\hline Work status & $\begin{array}{l}0.46^{* * *} \\
(0.03)\end{array}$ & $\begin{array}{l}0.37^{* * *} \\
(0.03)\end{array}$ & $\begin{array}{l}0.40^{* * *} \\
(0.04)\end{array}$ & $\begin{array}{l}0.37^{* * *} \\
(0.03)\end{array}$ & $\begin{array}{l}0.36^{\text {*** }} \\
(0.03)\end{array}$ & $\begin{array}{l}0.37^{* * * *} \\
(0.03)\end{array}$ \\
\hline Fear of failure & $\begin{array}{l}-0.20^{* * *} \\
(0.02)\end{array}$ & $\begin{array}{l}-0.11^{* * *} \\
(0.02)\end{array}$ & $\begin{array}{l}-0.19^{* *} \\
(0.03)\end{array}$ & $\begin{array}{l}-0.11^{* * *} \\
(0.03)\end{array}$ & $\begin{array}{l}-0.10^{* *} \\
(0.03)\end{array}$ & $\begin{array}{l}-0.11^{* * *} \\
(0.03)\end{array}$ \\
\hline \multicolumn{7}{|l|}{ Controls: Country level } \\
\hline GDP per capita & $\begin{array}{l}-0.08 \\
(0.15)\end{array}$ & $\begin{array}{l}-0.10 \\
(0.14)\end{array}$ & $\begin{array}{l}-0.17 \\
(0.17)\end{array}$ & $\begin{array}{l}-0.10 \\
(0.15)\end{array}$ & $\begin{array}{l}-0.22 \\
(0.24)\end{array}$ & $\begin{array}{l}-0.07 \\
(0.18)\end{array}$ \\
\hline GDP growth & $\begin{array}{l}-0.18 \\
(0.13)\end{array}$ & $\begin{array}{l}-0.19 \\
(0.12)\end{array}$ & $\begin{array}{l}-0.09 \\
(0.12)\end{array}$ & $\begin{array}{l}-0.19 \\
(0.12)\end{array}$ & $\begin{array}{l}-0.21 \\
(0.13)\end{array}$ & $\begin{array}{l}-0.19 \\
(0.12)\end{array}$ \\
\hline Unemployment & $\begin{array}{l}0.01 \\
(0.12)\end{array}$ & $\begin{array}{l}0.02 \\
(0.11)\end{array}$ & $\begin{array}{l}0.05 \\
(0.11)\end{array}$ & $\begin{array}{l}0.02 \\
(0.12)\end{array}$ & $\begin{array}{l}0.01 \\
(0.11)\end{array}$ & $\begin{array}{l}0.01 \\
(0.12)\end{array}$ \\
\hline Government spending & $\begin{array}{l}-0.12 \\
(0.14)\end{array}$ & $\begin{array}{l}-0.15 \\
(0.13)\end{array}$ & $\begin{array}{l}-0.08 \\
(0.14)\end{array}$ & $\begin{array}{l}-0.14 \\
(0.14)\end{array}$ & $\begin{array}{l}-0.14 \\
(0.13)\end{array}$ & $\begin{array}{l}-0.11 \\
(0.15)\end{array}$ \\
\hline $\begin{array}{l}\text { Commercial financial system (Commercial } \\
\text { FS) }\end{array}$ & & & $\begin{array}{l}-0.18 \\
(0.12)\end{array}$ & & & \\
\hline Philanthropic financial system (Phil FS) & & & & $\begin{array}{l}-0.06 \\
(0.16)\end{array}$ & & \\
\hline Educational system (ES) & & & & & $\begin{array}{l}-0.06 \\
(0.23)\end{array}$ & \\
\hline Political system (PS) & & & & & & $\begin{array}{l}-0.19 \\
(0.20)\end{array}$ \\
\hline \multicolumn{7}{|l|}{ Explanatory variables } \\
\hline Individual human capital (IndHC) & & $\begin{array}{l}0.67^{* * *} \\
(0.03)\end{array}$ & $\begin{array}{l}0.83^{* * *} \\
(0.03)\end{array}$ & $\begin{array}{l}0.67^{* * *} \\
(0.03)\end{array}$ & $\begin{array}{l}0.71^{\text {*** }} \\
(0.03)\end{array}$ & $\begin{array}{l}0.67^{\text {*** }} \\
(0.03)\end{array}$ \\
\hline Individual financial capital (IndFC) & & $\begin{array}{l}0.08^{* * *} \\
(0.04)\end{array}$ & $\begin{array}{l}0.07^{\dagger} \\
(0.04)\end{array}$ & $\begin{array}{l}0.08^{*} \\
(0.04)\end{array}$ & $\begin{array}{l}0.07^{\dagger} \\
(0.04)\end{array}$ & $\begin{array}{l}0.08^{*} \\
(0.04)\end{array}$ \\
\hline Individual social capital (IndSC) & & $\begin{array}{l}0.71^{\text {*** }} \\
(0.03)\end{array}$ & $\begin{array}{l}0.66^{* * *} \\
(0.03)\end{array}$ & $\begin{array}{l}0.71^{* * *} \\
(0.03)\end{array}$ & $\begin{array}{l}0.69^{\text {*** }} \\
(0.03)\end{array}$ & $\begin{array}{l}0.70^{\text {**** }} \\
(0.03)\end{array}$ \\
\hline \multicolumn{7}{|l|}{ Cross-level interaction terms } \\
\hline IndFC x Commercial FS & & & $\begin{array}{l}-0.02 \\
(0.05)\end{array}$ & & & \\
\hline IndFC x Phil FS & & & & $\begin{array}{l}0.11^{* *} \\
(0.03)\end{array}$ & & \\
\hline IndHC $x$ ES & & & & & $\begin{array}{l}0.27^{* * *} \\
(0.02)\end{array}$ & \\
\hline IndFC $x$ PS & & & & & & $\begin{array}{l}0.08^{*} \\
(0.03)\end{array}$ \\
\hline IndHC $x$ PS & & & & & & $\begin{array}{l}0.19^{* * * *} \\
(0.03)\end{array}$ \\
\hline IndSC x PS & & & & & & $\begin{array}{l}-0.03 \\
(0.02)\end{array}$ \\
\hline Constant (individual level) & $\begin{array}{l}-2.76^{\dagger} \\
(1.53)\end{array}$ & $\begin{array}{l}-2.88^{*} \\
(1.45)\end{array}$ & $\begin{array}{l}-5.69^{*} \\
(1.70)\end{array}$ & $\begin{array}{l}-2.85^{\dagger} \\
(1.54)\end{array}$ & $\begin{array}{l}-1.67^{\dagger} \\
(2.43)\end{array}$ & $\begin{array}{l}-3.14^{\dagger} \\
(1.87)\end{array}$ \\
\hline Log-likelihood & -20973 & -16771 & -15003 & -16767 & -16713 & -16720 \\
\hline No of observations & 110259 & 81243 & 75654 & 81243 & 81243 & 80832 \\
\hline
\end{tabular}




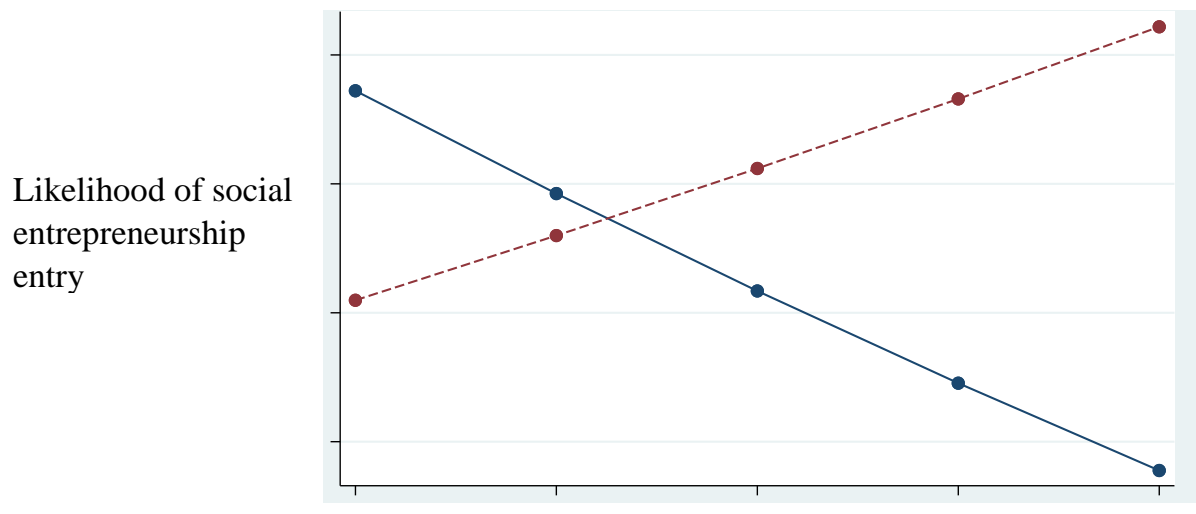

Low philanthropy financial system

High philanthropy financial system

Figure 2. Interaction effect between financial capital and philanthropy-oriented financial system on social entrepreneurship entry (Solid line represents low financial capital while dotted line represents high financial capital).

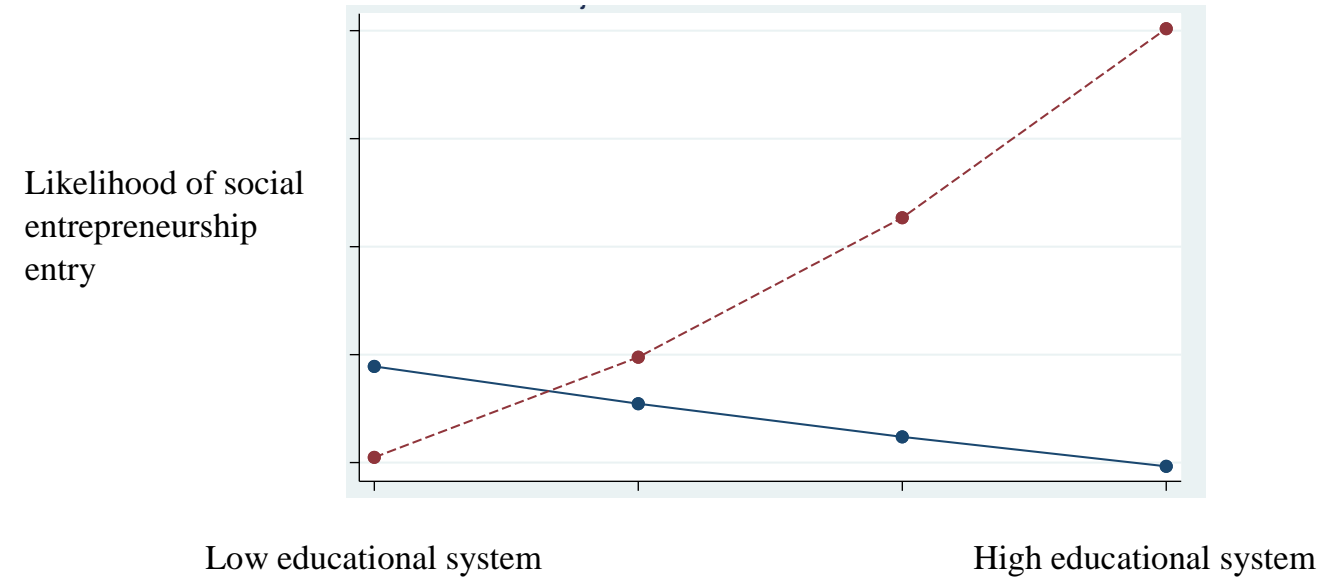

Figure 3. Interaction effect between human capital and educational system on social entrepreneurship entry (Solid line represents low human capital while dotted line represents high human capital).

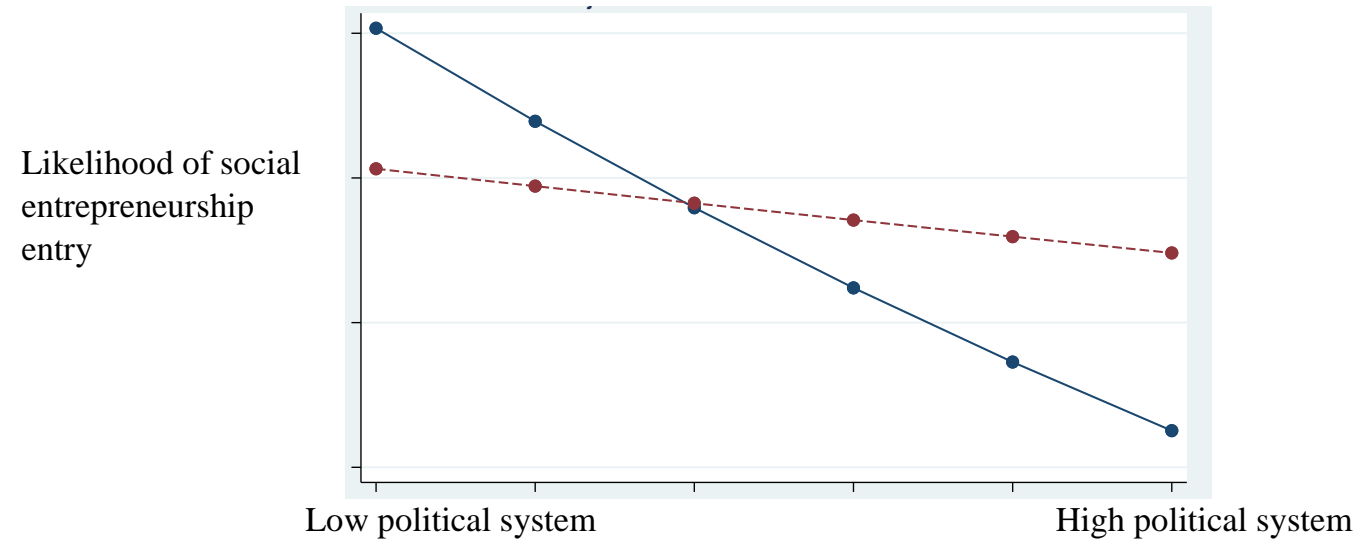

Figure 4. Interaction effect between financial capital and political system on social entrepreneurship entry (Solid line represents low financial capital while dotted line represents high financial capital). 
Likelihood of social entrepreneurship entry

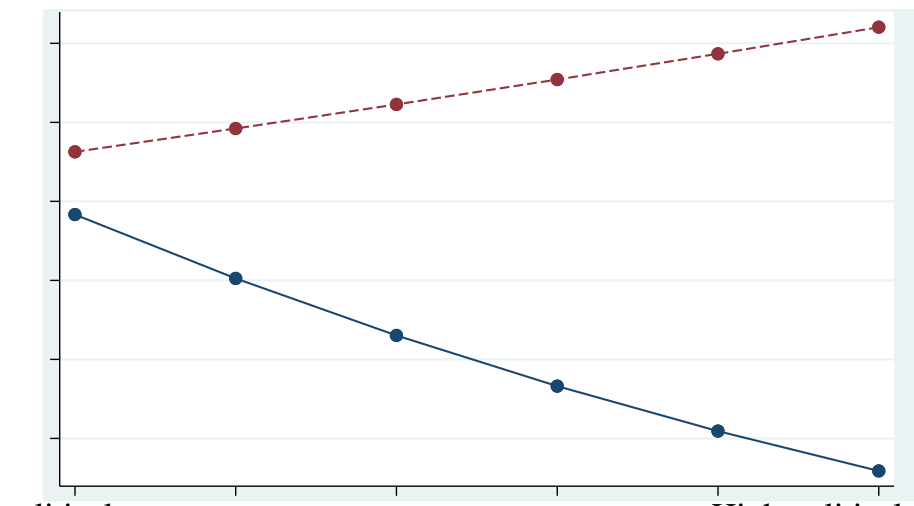

Low political system

High political system

Figure 5. Interaction effect between human capital and political system on social entrepreneurship entry (Solid line represents low human capital while dotted line represents high human capital). 